\title{
A PRINCIPLED STATUTORY APPROACH TO SUPPLEMENTAL JURISDICTION
}

\author{
RICHARD D. FREER*
}

"Supplemental jurisdiction" is a generic term encompassing the concepts of ancillary and pendent jurisdiction. ${ }^{1}$ In either form, supplemental jurisdiction permits the efficient packaging of litigation in federal court ${ }^{2}$ by allowing joinder of claims over which there is no independent basis of jurisdiction. ${ }^{3}$ Despite its usefulness, the doctrine has had a checkered career, richly earning its nickname "child of necessity and sire of confusion." "4

The principal source of confusion is the Supreme Court's consistent failure to discern and discuss in a principled fashion the statutory autliorization for the exercise of supplemental jurisdiction. Article III requires that Congress prescribe the jurisdiction of the lower federal courts. With

* Associate Professor of Law, Emory University. B.A. 1975, University of California, San Diego; J.D. 1978, UCLA. I am grateful to Howard E. Abrams, Donald W. Fyr and Mary Kay Kane for their helpful comments on an earlier draft. I am especially indebted to Thomas $C$. Arthur, who participated in hours of debate and discussion that forged and clarified many of the ideas in this article. Sara Beth Brody, Emory Law School Class of 1987, provided valuable research assistance. The Emory University Research Committee provided generous financial support.

1. A considerable body of recent literature suggests that there is no meaningful distinction between pendent and ancillary jurisdiction. This literature calls for an inclusive doctrine outlining federal court jurisdiction over claims that fail to satisfy statutory bases for original federal subject matter jurisdiction. See, eg., Matasar, A Pendent and Ancillary Jurisdiction Primer: The Scope and Limits of Supplentental Jurisdiction, 17 U.C. DAvIS L. REV. 103, 150-57 (1983); Note, A Closer Look at Pendent and Ancillary Jurisdiction: Toward a Theory of Incidental Jurisdiction, 95 HARV. L. REv. 1935, 1937 (1982); Comment, Pendent and Ancillary Jurisdiction: Towards a Synthesis of Two Doctrines, 22 UCLA L. REv. 1263, 1271-87 (1975). Although the Supreme Court has recognized the similarity between pendent and ancillary jurisdiction, it has refused to decide whether they constitute a single doctrine. See Owen Equip. \& Erection Co. v. Kroger, 437 U.S. 365, 370 n.8 (1978) (recognizing that ancillary and pendent jurisdiction stem from the same problem); Aldinger v. Howard, 427 U.S. 1, 13 (1976) (finding "little profit in attempting to decide whether ... there are any 'principled' diferences" between pendent and ancillary jurisdiction). Under the traditional view, pendent jurisdiction is exercised over nonfederal claims asserted by a plaintiff as part of a federal question suit. Ancillary jurisdiction involves claim or party joinder instituted by a party or nonparty. See J. FriedenthaA, M. KANe \& A. Miller, CiviL Procedure § 2.14, at 77-78 (1985); Matasar, supra, at 117-18.

2. The trend toward inclusive packaging of disputes is well documented. See, eg., Freer, Rethinking Compulsory Joinder: A Proposal to Restructure Federal Rule 19, 60 N.Y.U. L. REv. 1061, $1061-73$ (1985); Matasar, supra note 1, at 106-18; McCoid, A Single Package for Multiparty Disputes, 28 STAN. L. REv. 707 (1976).

3. Throughout this article, "jurisdiction" refers to subject matter jurisdiction; personal jurisdiction is assumed.

4. Fraser, Ancillary Jurisdiction and Joinder of Claims, 33 F.R.D. 27, 45 (1963). 
regard to the original jurisdiction of these courts, the Supreme Court has done two things. First, it has expressed great concern with the scope of the congressional grants, specifically undertaking the task of construing the statutory language. Second, it has construed those grants far more narrowly than the Constitution or the language of the statutes would require. This caution and circumspection bespeak concerns regarding federalism and respect for the limited nature of federal jurisdiction.

The Court has treated supplemental jurisdiction in a wholly different fashion. For over a century, it recognized and greatly expanded the scope of supplemental jurisdiction without a single mention of statutory authorization. In stark contrast to its treatment of original jurisdiction, the Court has been anything but cautious or restrictive. It has boldly asserted supplemental jurisdiction to the full constitutional limit, asserting power over all claims that have a sufficient transactional relationship to be included in a single "case or controversy."

The judiciary's consistent failure to so much as mention statutory authorization, much less acknowledge the need for it, has led many to conclude that supplemental jurisdiction is a form of common law subject matter jurisdiction. ${ }^{5}$ But in view of the requirements of Article III, that term is an oxymoron. Uniess the judiciary has unconstitutionally usurped legislative power for a century, there inust be some statutory basis for supplemental jurisdiction.

In the mid-1970's, the Court finally addressed the issue of congressional authorization of supplemental jurisdiction. But neither Aldinger $v$. Howard ${ }^{6}$ nor Owen Equipment \& Erection Co. v. Kroger ${ }^{7}$ established a principled, comprehensive approach. Instead, the Court in each case looked for evidence of specific congressional intent to preclude the use of supplemental jurisdiction under the specific circumstances presented. This approach is fundamentally flawed. The search for congressional preclusion of jurisdiction assumes that Congress had previously granted authority over supplemental claims. Yet the Court never identified the source of that grant, and thus failed to establish a statutory basis for the principled resolution of supplennental jurisdiction questions. In short, the Court sanctioned an ad hoc search for legislative intent despite the rather obvious fact that Congress, in passing the general jurisdictional statutes, has never expressly considered supplemental jurisdiction. As a

5. See, e.g., J. FRIEDENTHAL, M. KANE \& A. MiLLER, supra note $1, \S \S 2.12-2.14$ (discussing ancillary and pendent jurisdiction under the rubric "judicially created jurisdiction"); F. JAMES \& G. Hazard, Civil Procedure, \$ 2.7, at 61-62 (3d ed. 1985) (ancillary and pendent jurisdiction described as "product[s] of decisional law rather than statute").

6. 427 U.S. 1 (1976).

7. 437 U.S. 365 (1978). 
result, the law of supplemental jurisdiction is more confused today than it was before the Court spoke.

I propose a new, principled approach to the question of congressional authorization of supplemental jurisdiction, one that identifies the source of the statutory grant of supplemental jurisdiction and recognizes its policy underpinnings. Supplemental jurisdiction is rooted in those portions of the jurisdictional statutes granting power over a "civil action." That Congress, in effect, delegated to the judiciary the power to define that term is shown not only by the statutory language but also by its delegation to the Supreme Court of the power to prescribe the joinder rules that establish the scope of the hitigative unit.

My approach requires study of the two distinct, and seemingly imconsistent, lines of cases mentioned above, as well as related portions of the jurisdictional statutes. The consistently narrow interpretations of original jurisdiction are based on those parts of the statutes relating to the basis of jurisdiction, such as federal question or diversity of citizenship. In contrast, the supplemental jurisdiction cases are based on the statutory phrase giving jurisdiction over an entire civil action, not just the jurisdiction-invoking claim. Each portion of the statute is supported by important policies; while the narrow construction of original jurisdiction respects federalism and avoids overwhelming federal court workloads, the broad construction of supplemental jurisdiction, when combined with the jomder rules, promotes efficient packaging of disputes and avoids duplicative litigation and the risk of inconsistent results.

The proper resolution of any supplemental jurisdiction problem, then, requires recognition of these separate statutory bases and policies. Each line of authority should be allowed to operate in its proper sphere. After the narrow restrictions on invocation of jurisdiction have been satisfied, the court will have fulfilled the policies underlying those restrictions. Then it should flesh out the scope of the entire civil action through the joinder rules and supplemental jurisdiction, effectuating the separate policies that support entertaming the entire civil action. It is here that the Supreme Court erred in Aldinger and Kroger. By failing to recognize that it was dealing with separate statutory authorizations and policies, the Court imported the restrictions on invocation of original jurisdiction into the supplemental jurisdiction realm, where such restrictions simply are not appropriate.

Part I of this article traces the development of the line of cases narrowing the statutory provisions for the invocation of federal jurisdiction, identifying the policies underlying that development both from a public- 
interest and an interest-group perspective. ${ }^{8}$ Part II contains a similar analysis of the line of cases developing broad supplemental jurisdiction and discusses the tension between the two lines.9 Part III reconciles the narrow and the broad jurisdictional readings, setting forth a statutory model for supplemental jurisdiction that debunks the inyth of common law subject matter jurisdiction and sets forth a principled, consistent method for approaching supplemental jurisdiction problems. ${ }^{10}$ Part IV contrasts that model's resolution of Aldinger and Kroger with the Court's actual treatment of these two cases. ${ }^{11}$ Finally, Part $V$ assesses the impact of Aldinger and Kroger, and concludes that they fail to establish any principles for dealing with congressional authorization of supplemental jurisdiction. ${ }^{12}$

\section{NARROW INTERPRETATIONS OF JURISDICTIONAL GRANTS}

The Constitution sets the outer boundaries of federal jurisdiction, permitting Congress to empower the lower federal courts to entertain "cases or controversies" falling within those boundaries. ${ }^{13}$ This jurisdiction is not self-executing; Congress must prescribe it. ${ }^{14}$ The Supreme Court has consistently given narrow readings to the statutory language used by Congress to establish jurisdictional bases. ${ }^{15}$ The two most important bases of federal court jurisdiction-diversity of citizenship and general federal question-provide good examples.

\section{A. Background and History.}

The Judiciary Act of 1789 empowered the lower federal courts to hear diversity cases. ${ }^{16}$ Although the relevant language mirrored that of

8. See infra notes $13-80$ and accompanying text.
9. See infra notes $81-122$ and accompanying text.
10. See infra notes $123-51$ and accompanying text.
11. See infra notes $152-212$ and accompanying text.
12. See infra notes $213-24$ and accompanying text.
13. U.S. CONST. art. III, $\$ 2$. See generally P. BATOR, D. SHAPIRO, P. MISHKIN \& H. WECHSIER, HART AND WeChSLER'S The Federal CoURTS AND tHe Federal System 309-438 (2d ed. 1973) [hereinafter HART \& WECHSLER].

14. See Cary v. Curtis, 44 U.S. (3 How.) 236, 245 (1845) ("[T] he judicial power of the United States ... is ... dependent for its distribution and organization, and for the modes of its exercise, entirely upon the action of Congress ....."). Although this proposition is considered axiomatic today, it resulted from a long judicial struggle and arguably is not consistent with the intent of the framers. See Clinton, $A$ Mandatory View of Federal Court Jurisdiction: Early Implementation of and Departures from the Constitutional Plan, 86 CoLUM. L. REv. 1515, 1616 (1986).

15. See generally $13 \mathrm{C}$. WRIGHT, A. Miller \& E. COOPER, Federal Practice AND ProceDURE § 3526, at 232 (2d ed. 1984). See also infra text accompanying notes 16-80. (1982)).

16. Judiciary Act of 1789, ch. $20, \S 11,1$ Stat. 73, 78 (current version at 28 U.S.C. $\S 1332$ (a)(1) 
the Constitution, ${ }^{17}$ the Supreme Court in Strawbridge v. Curtiss ${ }^{18}$ interpreted the statute to require complete diversity between all plaintiffs and all defendants. ${ }^{19}$ The Court gave no reason for its restrictive reading; it pointed to no legislative history or indication of congressional intent, nor did it purport to rely on the slight linguistic differences between tlie statute and tlie Constitution.

Congress has revised the diversity statute eight times in the ensuing two centuries. ${ }^{20}$ Yet it has never either expressly incorporated the complete diversity rule into the statute or expressly rejected it. Thus the complete diversity requirement survives, on the theory that Congress implicitly adopted it in the subsequent reenactments. ${ }^{21}$

Despite the statute's almost verbatim use of the relevant constitutional language, ${ }^{22}$ the Court has also interpreted the grant of general federal question jurisdiction narrowly. ${ }^{23}$ It has used two devices to narrow federal question jurisdictional statutes: a limited interpretation of

17. The Constitution provides for jurisdiction over controversies "between Citizens of different States." U.S. CONST, art. III, § 2. The Judiciary Act of 1789 provided for diversity jurisdiction when a "suit [was] between a citizen of the state where the suit [was] brought, and a citizen of another state" and the amount in controversy exceeded \$500. Judiciary Act of 1789, ch. 20, §11, 1 Stat. 73, 78. The statute is today codified at 28 U.S.C. $\S 1332$ (a)(1) (1982), and provides for jurisdiction over "all civil actions where the matter in controversy exceeds the sum or value of $\$ 10,000 \ldots$ and is between ... c citizens of different States."

18. 7 U.S. (3 Cranch) 267 (1800).

19. See infra notes 199-211 and accompanying text.

20. Act of Mar. 3, 1875, ch. 137, §1, 18 Stat. 470,470 (pt. 3) (setting amount-in-controversy requirement at $\$ 500$ for diversity actions); Act of Mar. 3, 1887, ch. 373, $\$ 1,24$ Stat. 552, 552-53 (increasing amount-in-controversy requirement to \$2000); Act of Mar. 3, 1911, ch. 231, Pub. L. No. 61-475, § 24, 36 Stat. 1087, 1091-94 (i1creasing amount-in-controversy requirement to $\$ 30 \mathrm{C0}$ ); Act of Apr. 20, 1940, ch. 117, Pub. L. No. 76-463, 54 Stat. 143, 143 (providing that the District of Columbia and the territories of Alaska and Hawaï be treated as states for purposes of diversity jurisdiction); Act of July 26, 1956, Pub. L. No. 84-808, 70 Stat. 658 (providing that Puerto Rico be treated as a state for purposes of diversity jurisdiction); Act of July 25, 1958, Pub. L. No. 85-554, $\$ 2,72$ Stat. 415, 415 (increasing amount-in-controversy requirement to \$10,000); Act of Aug. 14, 1964, Pub. L. No. 88-439, §1, 78 Stat. 445, 445 (defining corporate citizenship for purposes of diversity jurisdiction); Act of Oct. 21, 1976, Pub. L. No. 94-583, § 3, 90 Stat. 2891, 2891 (extending diversity jurisdiction to encompass actions brought by a foreign state against citizens of a state).

21. See infra notes $41-42$ and accompanying text (discussing implicit adoption as a traditional canon of statutory construction).

22. The Constitution provides for jurisdiction over "Cases, in Law and Equity, arising under this Constitution, the Laws of the United States, and Treaties made, or which shall be made, under their Authority." U.S. CONST. art. III, §2. The original general federal question statute provided for jurisdiction over "any suits of a civil nature, at law or in equity ... arising under the Constitution or laws of the United States, or treaties made, or which shall be made, under their authority ...." Act of Mar. 3, 1875, ch. 137, § 2, 18 Stat. 470, $470-73$ (pt. 3). The statute is today codiffied at 28 U.S.C. § 1331 (1932), and provides for jurisdiction over "all civil actions . . . aris[ing] under the Constitution, laws, or treaties of the United States."

23. See infra notes $24-33$ and accompanying text. 
whether a claim "arises under" federal law, and the "well-pleaded complaint" rule.

The first of these devices concerns the quantum of federal material that must be present to invoke federal question jurisdiction. In Osborn $v$. Bank of the United States, ${ }^{24}$ the Court held that constitutional power existed whenever federal law was an ingredient in the cause of action. ${ }^{25}$ A similar reading of the legislative grant of federal question jurisdiction would have opened the fioodgates to a torrent of cases. ${ }^{26}$ Although the Court in the Pacific Railroad Removal Cases ${ }^{27}$ interpreted the statute as coextensive with the constitutional grant, it quickly perceived the potential workload problem and "acted understandably in giving a restrictive reading to the statute." 28 The resulting interpretation of the statutory "arising under" phrase is narrower than the interpretation given the constitutional grant in Osborn.29

The second device the Court has used to narrow federal question jurisdiction is the "well-pleaded complaint" rule. Louisville \& Nashville

24. 22 U.S. (9 Wheat.) 738 (1824).

25. Id. at 819-20. See also C. Wright, The LaW of FEDERAL CourTs $\S 17$, at 92.94 (4th ed. 1983) (discussing impact of Osborn); Matasar, Rediscovering "One Constitutional Case": Procedural Rules and the Rejection of the Gibbs Test for Supplemental Jurisdiction, 71 CalIF. L. REv. 1399, 1409-17 (1983) (tracing development of supplenental jurisdiction and discussing Osborn).

26. For example, such a reading would have provided for jurisdictiou over title disputes in which title is traceable to an original federal grant, "even though the controverted questions normally are of fact or of local land law." T.B. Harms Co. v. Eliscu, 339 F.2d 823, 826 (2d Cir. 1964), cert. denied, 381 U.S. 915 (1965). See Shoshone Mining Co. v. Rutter, 177 U.S. 505 (1900) (rejecting federal jurisdiction in such a situation).

27. 115 U.S. 1 (1885) (upholding federal question jurisdiction over common law tort actions against federally chartered railroads). The Court later described the case as an "unfortunate decision.” Romero v. International Terminal Operating Co., 358 U.S. 354, 379 n.50 (1959). Congress remedied the problem created by the case with legislation providing that federal question jurisdiction may be based on a corporation's federal charter only if the United States owns inore than half of the capital stock of the corporation. See 28 U.S.C. $\$ 1349$ (1982). But see International Refugee Org. v. Republic S.S. Corp., 189 F.2d 858, 860 (4th Cir. 1951) (providing for federal jurisdiction over state clains by international organizations authorized by federal statute to "institute legal proceedings").

28. C. WRIGHT, supra note $25, \S 17$, at 92 .

29. See Romero, 358 U.S. at 379 n.51 ("[T]he many limitations which have been placed on jurisdiction under $\S 1331$ are not limitations on the constitutional power of Congress to confer jurisdiction on the federal courts."). This process of narrowing the statutory reach continues today. See Merrell Dow Pharmaceuticals Inc. v. Thompson, 106 S. Ct. 3229 (1986), noted in The Supreme Court, 1985 Term, 100 HARV. L. REv. 1, 230-40 (1986).

Although courts and commentators agree that the statutory phrase "arising under" is interpreted more narrowly than the constitutional grant, there is little consensus on the precise scope of that interpretation. See C. WRIGHT, supra note $25, \S 17$, at 93 (noting that although Osborn has been rejected as a statutory theory, "[i]t is not easy to state what has been substituted in its stead"); see also HART \& WECHSLER, supra note 13, at 844-926; M. REDISH, FEDERAL JURISDICTION: TENSIONS IN THE Allocation Of JUdicial Power 53-77 (1980); Cohen, The Broken Compass: The Requirement that a Case Arise "Directly" Under Federal Law, 115 U. PA. L. REv. 890 (1967); Currie, The Federal Courts and the American Law Institute (Part II), 36 U. CHI. L. REv. 268, 27679 (1969); Mishkin, The Federal "Question" in the District Courts, 53 CoLUM. L. REv. 157 (1953). 
Railroad Co. v. Mottley ${ }^{30}$ contains the most famous statement of this rule: the basis for the federal court's jurisdiction must appear on the face of a proper complaint, and may not be based on federal issues raised by way of defense or counterclaim. ${ }^{31}$ The rule can result in a federal court's having no jurisdiction in a case that centers on federal law. ${ }^{32}$ The narrow interpretation of the federal question statute has often resulted in issues of federal substantive law being decided by state courts. ${ }^{33}$

There are strong policy reasons for construing jurisdictional statutes more narrowly than the corresponding constitutional grants; most coinmentators note that the Constitution is by nature a general document, and that Congress has been left room to grant such specific portions of the whole as it deems necessary. ${ }^{34}$ Although there is support for concluding that Congress intended to extend jurisdiction to the constitutional limit with both diversity and federal question jurisdiction, ${ }^{35}$ the Court has consistently resisted this conclusion.

30. 211 U.S. 149 (1908).

31. Id. at 153-54. I use the term "proper complaint" to refiect the Court's holding that jurisdiction cannot be based on the anticipation in a complaint of a federal issue that might be raised by a defense to that complaint. See id. at 152-54; see also J. FrIEDENTHAI, M. KANE \& A. MiLLER, supra note $1, \S 2.4 ;$ F. JAMES \& G. HAZARD, supra note $5, \S 2.6$; C. WRIGHT, supra note $25, \S 18$.

32. This is true even with respect to a matter ostensibly entrusted exclusively to the federal courts. See generally J. FRIEDENTHAL, M. KANE \& A. MilleR, supra note 1, § 2.4, at 23-24. For example, assume an action in state court by a patentee to collect royalties owed by his licensee for use of a patented device. The licensee defends by asserting that the patent is void for want of originality. Absent diversity, the case cannot be removed. There is no federal question jurisdiction, simce the federal issue is injected into the case by way of defense, and would not appear in a well-pleaded complaint as required by Mottley. Yet the major issue to be resolved in the case is the validity of the patent. Even though federal courts have by statute exclusive jurisdiction over "any civil action arising under any Act of Congress relating to patents," 28 U.S.C. § 1338(a) (1982), this case will be decided by a state court. See, eg., Lear, Inc. v. Adkins, 395 U.S. 653 (1969); see also Chisum, The Allocation of Jurisdiction Between State and Federal Courts in Patent Litigation, 46 WASH. L. REV. $633,657-64$ (1971).

33. The rule's value as a relatively simple test applied to the initial pleading of the suit is generally thought to outweigh this "loss" of cases to state court. See J. FRIEDENTHAI, M. KANE \& A. MILLER, supra note 1, $\S 2.4$, at 23 ("Given the limited nature of federal subject inatter jurisdiction, it is essential that the existence of jurisdiction be determined at the outset, rather than being contingent upon what may occur at later stages in the litigation."). Nonetheless, the rule has not been the subject of umiversal praise. Id. $\S 2.4$, at 22-24; C. WRIGHr, supra note $25, \S 18$, at 98-102. Moreover, it is not a simple rule when declaratory relief is sought. See id., $\S 18$, at 100-02.

34. See generally HART \& WECHSLER, supra note 13, at 870-73 (discussing the extent to which statutory grants of federal question jurisdiction by Congress in 1789 and 1875 did not confer the entire scope of jurisdiction allowed by the Constitution, despite the use of language identical to that found in the Constitution). There are several strong policies supporting narrow statutory construction. See infra text accompanying notes 36-53.

35. This is especially so with regard to the federal question statute. See infra text accompanying notes 38-39. 


\section{B. Traditional Canons of Statutory Construction and the Emergence of a Consistent Policy.}

Two traditional canons of statutory construction ${ }^{36}$ have played a significant role in the narrow readings of grants of original jurisdiction. The Court has ignored one traditional canon, the plain meaning rule, and has adhered rigorously to another, the canon of implicit adoption. The result has been a consistent policy of narrow construction.

The plain meaning rule requires that the legislature be taken at its word when it uses langnage of clear meaning. ${ }^{37}$ This canon prohibits reference to anything other than the terms of the statute, much as the parol evidence rule precludes use of extrinsic evidence to alter the meaning of a written contract. Like the parol evidence rule, the plain meaning rule was eroded when courts began to look to legislative history as evidence of the legislature's true intent.

The Supreme Court ignored this rule when it formulated its original narrow interpretations of the jurisdictional statutes. Under the plain meaning rule, the original diversity statute would have extended jurisdiction to the constitutional limit, since the statute tracked the relevant constitutional language. Only soine pohicy, which Congress did not state and which Chief Justice Marshall declined to discuss in Strawbridge, could have justified the narrower construction.

There is even inore evidence that Congress intended that the original general federal question statute embrace the entire quantum of constitutionally permissible jurisdiction. Not only did the statute's drafter track the relevant constitutional langnage, lie also stated in floor debate that the intent was to vest the entire constitutional federal question jurisdiction. ${ }^{38}$ Indeed, based on his interpretation of Supreme Court prece-

36. See generally J. Hurst, Dealing WITH StatuTes 56-65 (1982); J. SUTHeRLAND, STatUTES AND STATUTORY CONSTRUCTION (4th ed. 1972). There is increasing interest in the traditional canons, no doubt due in part to the Supreme Court's increasing interest in legislative history. See Carro \& Brann, The U.S. Supreme Court and the Use of Legislative Histories: A Statistical Analysis, 22 JURIMETRICS J. 294 (1982); see also Harris, The Politics of Statutory Construction, 1985 B.Y.U. L. REV. 745, 787 (Court's use of "restrictive canons of construction used in the nineteenth century" has become "more common").

37. See R. Posner, The Federal Courts: Crisis and Reform 276-79 (1985); Wald, Some Observations on the Use of Legislative History in the 1981 Supreme Court Term, 68 Iowa L. REv. 195, 215-16 (1983).

38. Senator Matthew Carpenter, a member of the Judiciary Committee, drafted the general federal question statute and was manager of the bill in the Senate. See 2 CoNG. Rec. 4984 (1874); 3 CONG. REC. 2168 (1875). During the debate, he asserted that "[t]his bill gives precisely the power which the Constitution confers-nothing more, nothing less." 2 CoNG. REC. 4987 (1874). See also id. at 4985-86 (similar statements by Sen. Carpenter). Statements by the author or floor manager of legislation are traditionally entitled to substantial weight in legislative history analysis. See Wald, supra note 37 , at 201. 
dent, he thought that it would have been unconstitutional to do otherwise. ${ }^{39}$ Despite this evidence, the Court wasted no time in imposing "statutory" limitations; it espoused the well-pleaded complaint rule, for exainple, just two years after the statute was enacted. 40

Although it has ignored the plain ineaning canon, the Supreme Court has adhered scrupulously to the canon of implicit adoption, under which the reenactinent of a statute without criticism of judicial interpretations is considered a legislative adoption of those interpretations. ${ }^{41}$ The Court imitially interpreted the language of both the diversity and general federal question statutes narrowly. In each case, Congress reenacted the statute without changing it so as to "overrule" the narrowing precedent. The implicit adoption canon permits the federal courts to assume that Congress has adopted the Court's restrictive interpretations. ${ }^{42}$ Thus today we speak of the complete diversity rule and the well-pleaded complaint rule as "statutory requirements."

But they are not statutory at all, of course, at least not in the sense that Congress expressed them. The Court imposed them, and Congress did nothing to change the Court's imposition. It is not immediately or intuitively obvious that reenactment without ainendment justifies the conclusion that Congress intended to incorporate the restrictive interpretation. There is no gnarantee that members of Congress were aware of the judicial interpretations. Those who were may not have agreed with the interpretation and may have felt that the reenactment without cominent constituted a rejection of the restriction. ${ }^{43}$ There is simply no way to tell. 44

The leading studies of the history of the 1875 legislation are Chadbourn \& Levin, Original Jurisdiction of Federal Questions, 90 U. PA. L. REv. 639 (1942), and Forrester, Federal Question Jurisdiction and Section 5, 18 TUL. L. REv. 263 (1943).

39. 2 CONG. REC. 4986-87 (1874). Senator Carpenter was led to this conclusion by language in Martin v. Hunter's Lessee, 14 U.S. (1 Wheat.) 304, 330 (1810 ("If, then, it is a duty of congress to vest the judicial power of the United States, it is a duty to vest the whole judicial power."). See Forrester, supra note 38, at 277 n.36. That view, expressed in Martin by Justice Story, was not to prevail and indeed had been repudiated thirty years before Senator Carpenter's remarks. See Cary v. Curtis, 44 U.S. (3 How.) 236, 245 (1845). See also Clinton, supra note 14, at 1581-90 (discussing Martin and Cary).

40. Gold-Washing \& Water Co. v. Keyes, 96 U.S. 199, 203-04 (1877).

41. Even Judge Friendly, described as a "most trenchant critic" of the canons, R. POSNER, supra note 37, at 282, occasionally invoked this particular rule. See, eg., Phillips, Nizer, Benjamin, Kriin \& Ballon v. Rosenstiel, 490 F.2d 509, 514 (2d Cir. 1973).

42. See, e.g., Owen Equip. \& Erection Co. v. Kroger, 437 U.S. 365, 373 (1978); Snyder v. Harris, 394 U.S. 332, 339 (1969).

43. H. Fruendiy, Benchmarks 232-33 (1967).

44. As Judge Posner points out, this canon of statutory construction assumes legislative omniscience. R. POSNER, supra note 37, at 282-83. 
I do not suggest that the Court is disingenuous in this selective use of traditional canons. As Judge Wald has noted, selective invocation of the canons is quite proper. ${ }^{45}$ The canons are, in her colorful phrase, "drawn out as needed, much as a golfer selects the proper club when he gauges the distance to the pin and the contours of the course."46 And the result of the Court's selective use of the canons has been consistent: grants of original jurisdiction are read narrowly.

This consistent result is supported by compelling, though usually unarticulated, public policy. Strawbridge was but one of several cases in which the Marshall Court recognized strict limits on federal court power. ${ }^{47}$ Although the Court's interpretation seems inconsistent with Chief Justice Marshall's federalist politics, the historical and political context explains a great deal. The first decade of the nineteenth century was, of course, a period of great political tension during which the relations between the governmental branches were being tested. ${ }^{48}$ The Marshall Court's parsimony with diversity jurisdiction reflected a recognition of the national government's status as a sovereign of limited powers, and at the same time served to "deflect[] political attacks that might be mounted against judicial aggrandizement." 49 This limitation thus insulated the Court from criticism for overstepping the separation of powers principle at a tense time, and may have staved off legislative restrictions that would have hampered its growth as an institution. ${ }^{50}$

The restrictions on general federal question jurisdiction came about much later, of course, since that basis of jurisdiction was not established until 1875.51 As noted, these restrictions were from the outset seen as

45. Wald, supra note 37 , at $215-16$.

46. Id.

47. See generally 2 G. HASKINS \& H. JOHNSON, HISTORY OF THE SUPREME COURT OF THE UNITED STATES 614-18 (1981).

48. See generally id.; R. McCloskey, The AMERICAN SupREMe COURT 36-53 (1960).

49. 2 G. HASKINS \& $\mathrm{H}$. JoHNSON, supra note 47 , at 615.

50. The best example of the Marshall Court's brilliant acceptance of limitations on jurisdiction as part of consolidation of its own importance is Marbury v. Madison, 5 U.S. (1 Cranch) 137 (1803). In Marbury, the Court rejected legislative efforts to extend its power past constitutional himits, thereby simultaneously embarrassing President Jefferson and avoiding the confrontation with Congress that might have ensued if the Court had simply ignored these legislatively bestowed powers. See 2 G. HLASKINS \& H. JoHnson, supra note 47, at 615.

Chief Justice Marshall did not expressly recognize in Strawbridge that the Constitntion would permit a broader interpretation of diversity jurisdiction. Nonetheless it seems clear that he recognized that his holding was not constitutionally mandated. Years after Strawbridge, when the governmental tensions had abated, Marshall expressed regret about some of the restrictive opimions of the carly period of his judicial career, most notably Strawbridge. See Louisville C. \& C. R.R v. Letson, 43 U.S. (2 How.) 497, 555-56 (1844) (Justice Wayne recounting discussions with Marshall).

51. Act of Mar. 3, 1875, ch. 137, § 1, 18 Stat. 470, 470-73 (pt. 3) (current version at 28 U.S.C. \$ 1331 (1982)). See generally HaRT \& WeCHSLER, supra note 13, at 844-50 (tracing the complicated history of federal question jurisdiction). 
serving the purpose of docket control, useful not only to preclude a possibly crushing increase in caseload, but also to ferret out cases of little federal policy interest, such as disputes involving realty with title traceable to a federal grant. 52

These currents of public policy still support the narrow interpretation of statutory grants of jurisdiction, which respects the states' domain by limiting federal court intrusion in matters that state courts can easily decide. It also avoids swamping the federal courts with a caseload both quantitatively overwhelming and qualitatively unimportant. Finally, the Court's consistency gives Congress a bright-line test: if the legislature disagrees with the Court's interpretation of a statute, it must expressly "overrule" it in a reenactment.

All of these policies can be seen as in the public interest. Some are consistent, however, with private goals. For example, federal judges have a personal interest in the quantity and quality of their caseload. This natural interest suggests another way to assess the jurisdictional grants.

\section{The Resulting Symbiosis: Suggesting an Interest-Group Analysis of Jurisdictional Legislation.}

The interaction between the federal courts and Congress has led to an interesting symbiosis. Congress is fairly passive in this relationship. It lias reenacted the diversity and general federal question statutes without inuch more than some fine-tuning, such as straightening out corporate citizenship or adjusting the ainount-in-controversy requirement. ${ }^{54}$ It

52. See supra note 26.

53. Still, one wonders how Congress could ever succeed in vesting jurisdiction to the constitutional himit. If Congress intends to vest broad jurisdiction in the lower federal courts, the Court will apparently require it to do so by means of some sort of superlegislative action. Congress has already tried using the constitutional language and indicating in the legislative history that it intended to vest jurisdiction to the constitutional limit. See supra notes 38-39 and accompanying text.

It is unlikely that Congress conld succeed in overriding the implicit adoption canon by "overruling" the Court in successive legislation. Indeed, it would probably be more difficult to satisfy this superlegislative requirement than it is to override a presidential veto, even though the latter vote requires a supermajority. First, the presidential veto is a more direct rejection of the legislation than is a narrow judicial interpretation, which can be couched in reasonable terms regarding perceived linguistic ambiguities in the statute. Second, the veto will almost always be well publicized, making the legislation a topic of public discussion, possibly galvanizing Congress. Finally, the veto is iminediate, while the narrow judicial construction may take place years after the legislation passed, and thus may be presented to a body much different from the one that passed the statute, one that takes no offense at the judicial interpretation.

For a discussion of the relationship between the federal judiciary and Congress, see infra notes 54-80 and accompanying text.

54. See, e.g., Act of July 25, 1958, Pub. L. No. 85-554, § 2, 72 Stat. 415, 415 (increasing amount in controversy to $\$ 10,000$ and defining corporate citizenship); Act of Dec. 1, 1980, Pub. $L$. 
has done nothing to change the judicial restrictions on the invocation of jurisdiction, and thus has led the courts to assume that their restrictive interpretations have been accepted.

This relationship, and the jurisdictional statutes that spawned it, may be analyzed through the economic or interest-group model of legislation. Although by no means new, ${ }^{55}$ that model has received increasing attention in the scholarly literature recently, both as a general theory 56 and as an aid to understanding specific statutes. 57 Commentators, however, have not rigorously applied the model to jurisdictional legislation. Nor shall I. My purpose here is merely to suggest such an approach, as an alternative to the public-policy justifications discussed above.

The central theme of the interest-group model is that statutes are commodities sold by the legislature to the highest bidder. ${ }^{58}$ Thus legislation is essentially a bargain between the legislature and some interest group benefited by the legislation. The legislature and the interest group must rely on other governmental branches, including the courts, to act as agents to enforce the bargain. 59 These agents are presumed to be "rational economic actors" who will enforce the statute in a way that fosters their own concerns as inuch as possible. 60 To the extent that views of the agent diverge from those of the principal, the principal's goal may not be fully realized. Economists call these thwarting factors "agency costs."61

No. $96-486, \S 2,94$ Stat. 2369,2369 (eliminating amount-in-controversy requirement in federal question cases).

55. See, eg., The Federalist No. 10, at 56-65 (J. Madison) (J. Cooke ed. 1961) (discussing factions); JUSTICE OLIVER WENDELI HOLMES: HIS BOOK NOTICES AND UNCOLLECTED LETTERS AND PAPERS 108-09 (H. Shriver ed. 1936) (describing legislation as "a means by which a body, having the power, puts burdens which are disagreeable to them on the shoulders of somebody else"); see also Eastern R.R. Presidents Conference v. Noerr Motor Freight, Inc., 365 U.S. 127, 139 (1961) (asserting that it is not illegal "for people to seek action on laws in the hope that they may bring about an advantage to themselves and a disadvantage to their competitors").

56. See, eg., R. MCCORMICK \& R. Tollison, Polmílians, LEgislation and the ECONOMY: AN INQUIRY INTO THE INTEREST-GROUP THEORY OF GOVERNMENT (1981); Landes \& POSner, The Independent Judiciary in an Interest-Group Perspective, 18 J.L. \& EcoN. 875 (1975); Macey, Promoting Public-Regarding Legislation Through Statutory Interpretation: An Interest Group Model, 86 COLUM. L. REv. 223 (1986).

57. See, eg., Macey, Special Interest Groups Legislation and the Judicial Function: The Dilemma of Glass-Steagall, 33 EMORY L.J. 1 (1984); Maloney \& McCormick, A Positive Theory of Environmental Quality Regulation, 25 J.L. \& EcoN. 99 (1982).

58. See, eg., Landes \& Posner, supra note 56, at 877.

59. See, eg., Jensen \& Meckling, Theory of the Firm: Managerial Behaviour, Agency Costs and Ownership Structure, 3 J. Fin. EcoN. 305, 308 (1970).

60. See, e.g., Macey, supra note 56, at 244-46. See generally K. ARROW, EsSAYS IN THE THEORX OF RISK Benring 223-28; Klein, Crawford \& Alchian, Vertical Integration, Appropriable Rents, and the Competitive Contracting Process, 21 J.L. \& EcoN. 297 (1978).

61. My purpose here is to sketch the preliminary outline of an interest-group theory of jurisdictional legislation, upon which I intend to elaborate in a future article. As with any preliminary theoretical sketch, I run the risk of painting with too broad a brush. In general terms, I see the 
Jurisdictional statutes appear to fit this basic model nicely; they may be seen essentially as deals between the legislature and the organized bar. This relationship was made clear in 1978, when Congress rejected the nost recent proposal to abolish general diversity jurisdiction ${ }^{62}$-a proposal that was supported by the President, the Attorney General, the Chief Justice, ${ }^{63}$ and many other leading members of the federal bench. ${ }^{64}$

Simply put, the opposition-the organized bar-won Congress's favor. The ABA Board of Governors, the American Trial Lawyers Association, and state bars or bar committees from all fifty states opposed the legislation.65 This sentiment appeared to come from all parts of the profession. As one commentator reported, during the decade in which the proposal was before Congress in one form or another, "it is doubtful [whether] as many as two private practitioners ... ever appeared in support of it." $" 66$

Seen in these terms, the traditional scholarly debate regarding the

"deal" here as one between Congress and the organized bar. In reality, we might expect to find some
divergence of opinion within the bar as a whole. For example, one might expect small, rural law
firms to prefer abolition of diversity jurisdiction, which could increase their chances of doing battle
before the local state court judge. Large, national law firms, on the other hand, might prefer ex-
panded diversity jurisdiction; members of such firms inay feel more comfortable litigating in federal
court and may feel that state courts in smaller cities are biased.

One study indicates, however, that virtually all quarters of the practicing profession support the retention of diversity jurisdiction. See Frank, The Case for Diversity Jurisdiction, 16 HARv. J. ON LEGIs. 403, 404-05 \& n.3 (1979). But see Sheran \& Isaacman, State Cases Belong in State Courts, 12 Creighton L. Rev, 1, 52 (1978) ("The only groups who still argue strongly for diversity jurisdiction are the Association of Trial Lawyers of America, whose members specialize in personal injury litigation, and corporate lawyers whose clients prefer the federal courts.").

62. On two occasions in 1978, the House approved proposals to abolish general diversity jurisdiction, but neither bill reached a vote in the Senate. See 124 CONG. REC. 5008 (1978); 124 CoNG. REC. 33,546 (1978). These proposals prould have retained federal interpleader jurisdiction, a position embraced by most of those favoring abolition of general diversity jurisdiction. See C. WRIGHT, supra note $25, \S 23$, at 129.

63. See Frank, supra note 61 , at 404.

64. A number of leading federal judges, past and present, have made their positions known in the academic literature. See, eg., H. FriendLY, Federal JuRISDiction: A GENERAL VIEW 13952 (1973); R. JACKSON, THE SUPREME COURT IN THE AMERICAN SYSTEM OF GOVERNMENT 37 (1955); Frankfurter, Distribution of Judicial Power Between United States and State Courts, 13 CoRNELL L.Q. 499 (1928); Haynsworth, Book Review, 87 HARV. L. REV. 1082, 1089-91 (1974) (reviewing H. FRIENDLY, FEDERAL JURISDICTON: A GENERAL VIEW (1973)); see also Hearings on the State of the Judiciary, 95th Cong., 1st Sess. (1977) (views of Chief Justice Burger, Judge Bell, and Judge Friendly). Justice Brandeis also favored abolishing general diversity jurisdiction. See Friendly, Marching Into the Third Century, JUDGES' J., Spring 1977, at 6, 8. See generally Kastenmeier \& Remington, Court Reform and Access to Justice: A Legislative Perspective, 16 HARv. J. ON LEGIS. 301, 312-13 (1979) (describing the list of critics of diversity jurisdiction as "a lawyer's Hall of Fame"). But see Wright, The Federal Courts and the Nature and Quality of State Law, 13 WAYNE L. REV. 317 (1967) (federal judge favoring diversity jurisdiction).

65. Frank, supra note 61, at $404-05$ \& n.3.

66. Id. at 404. Few statistics on attorney preferences are available. One fairly recent poll of practicing lawyers showed that $69 \%$ opposed abolishing diversity jurisdiction, $26 \%$ favored aboli- 
historical and contemporary justifications for diversity jurisdiction ${ }^{67}$ pales. We do not keep diversity jurisdiction because of fear of local prejudice, or out of a desire to have federal judges retain facility with the common law, ${ }^{68}$ or for any of the reasons normally addressed in the scholarly debate. We keep diversity jurisdiction because a politically influential group wants it-for whatever reason-and is powerful enough to get Congress to reject every effort to take it away. ${ }^{69}$

We know hittle about why the bar wants diversity jurisdiction. Perhaps some meinbers agree with the traditional reasons set forth in the scholarly debate favoring diversity. More likely, they are motivated by more pragmatic considerations. Diversity jurisdiction provides an alternative forum, an option that lawyers can offer to clients.70 Possibly, the defense of diversity is nothing more than a knee-jerk reaction by a group that feels that a vested interest is being threatened. ${ }^{71}$ This may not be a traditional (or even a good) reason to retain diversity jurisdiction, but it may make sense to the interest group in position to lobby successfully for its continuing existence.

If the jurisdictional legislation may be seen as a bargain between the legislature and the bar, the agent charged with enforcement of the bargain is the federal judiciary. Yet, as the interest-group model would predict, this agent, when enforcing the bargain, seeks to advance its own goals. ${ }^{72}$ Every jurisdictional grant imcreases the workload of the federal judges; such legislation affects them directly and they have an imcentive to reduce the flow of cases into their courts. The federal judiciary's general antipathy toward diversity jurisdiction ${ }^{73}$ may be a response to this

tion, and 5\% were undecided. Law Poll of Affirmative Action, Judicial Selection, and Diversity of Citizenship Jurisdiction, 66 A.B.A. J. 148, 149 (1980). See also supra note 61.

67. The scholarly debate over retention of diversity jurisdiction continues to rage after two centuries and has generated an enormous literature. See generally 13B C. WRIGHT, A. MILLER \& E. COOPER, supra note $15, \$ \$ 3530-3531.1$, at $337-63$ (summary of arguments and citations to leading works).

68. These are among the several traditional justificatious for diversity jurisdiction. See id. at 339-43; Frank, supra note 61, at 409.

69. C. WRIGHT, supra note $25, \S 23$, at 137 (noting that the future of diversity jurisdiction will probably not be resolved on the merits, since "[a]ny proposal to modify diversity meets immediate organized opposition from those who believe that they have a vested interest in preserving, for their own advantage, the widest possible choice of forum").

70. Frank, supra note 61 , at 405 (abolition of diversity jurisdiction would "deprive the bar... of a resource which it values"). See also C. WRIGHT, supra note $25, \S 23$, at 135 (recognizing that litigants may use choice of forum for tactical purposes).

71. See supra note 69.

72. See supra text accompanying notes 58-61.

73. As noted, sketching a general preliminary theory always presents the danger of overgeneralization. I do not mean to imply that all federal judges favor abolition of diversity jurisdiction. Certainly, however, a noteworthy number of leading federal judges lave publicly taken that position. It may be that the reaction varies at trial and appellate levels. Appellate judges have written most of 
incentive. No doubt soine judges would abolish diversity to gain personal leisure. ${ }^{74}$ Others oppose diversity jurisdiction because they cannot render precedential decisions on matters of state law. ${ }^{75}$ And others resent the way diversity cases impose on their consideration and resolution of what they perceive as more challenging and important federal substantive legal questions. ${ }^{76}$

Of course, the bench has no incentive to strain relations with Congress.77 Although Article III judges enjoy life tenure and immunity from salary cuts, ${ }^{78}$ Congress can freeze judicial salaries and can cut funding for law clerks, secretaries, and office equipment from paper clips to word processors. ${ }^{79}$ This congressional power imposes praginatic limits on the federal judiciary's ability to maximize its own priorities.

Thus there are both strong public-policy and interest-group underpinnings supporting the narrow construction of statutory jurisdictional grants. From either standpoint, though, Congress has a recognized role in the developinent of policy. The courts, aware that they are interpreting statutes, address the statutory language and express concern with

the critical literature. See supra note 64 . Interestingly, however, many trial judges-those on whom the burden of diversity jurisdiction is greatest-have shown great sympathy to inclusive joinder in diversity cases, despite the Supreme Court's signal that they need not do so. See infra notes 220-24 and accompanying text.

74. See Landes \& Posner, Legal Change, Judicial Behavior, and the Diversity Jurisdiction, $9 \mathrm{~J}$. LEGAL STUD. 367, 369-70 (1980) ("IJ]udges, like other people, are rational maximizers of their satisfactions, which include not only pecuniary income but other things which people value, such as leisure, prestige, and power.").

75. As Judge Haynsworth has noted:

Erie took all the fun out of the diversity jurisdiction for the federal judge. If the state law is clear, ... the federal judge may only play the "ventriloquist's dummy to the courts of some particular state." If the state law is unclear, the federal judge is not free to search for the rule that should be applied. He is limited to gnessing what the highest court of a state would do if the case were before it.

Haynsworth, supra note 64, at 1089 (quoting Richardson v. Commissioner, 126 F.2d 562, 567 (2d Cir. 1942)).

76. See Landes \& Posner, supra note 74, at 369-72. I do not suggest that the federal bench is interested in the three-day work week. To the contrary, one of the principal argnments by judges against diversity jurisdiction is that it takes time away from federal question cases, as to which the federal bench is the only definitive arbiter. Diversity cases, on the other hand, involve state substantive law, as to which only state courts can give authoritative interpretations. In view of some federal court hostility toward diversity jurisdiction, see supra note 62 and accompanying text, one might expect federal courts to impose inore judicial restrictions in that type of case. Indeed, as suggested below, the Supreme Court's major supplemental jurisdiction cases of the 1970's may be seen as a statement of antidiversity bias unsupported by congressional sanction. See infra text accompanying notes 219-21.

77. Although Congress has accepted without criticism some jndicially imposed restrictions on the invocation of jurisdiction, see supra notes 13-35 and accompanying text, its consistent rejection of efforts to abolish diversity jurisdiction suggests that there are limits to the federal judiciary's leeway to impose restrictions on jurisdiction invocation.

78. U.S. CoNST. art. III, $\S 1$.

79. See Landes \& Posner, supra note 56, at 885. 
congressional intent. A sharp contrast to this approach is evident in the line of cases involving supplemental jurisdiction. Here, the courts broadly interpret the litigative unit witl little or no mention of congressional intent. The hegemony of the courts is so striking that inany observers lave concluded that supplemental jurisdiction constitutes common law development of subject matter jurisdiction. ${ }^{80}$

\section{BroAD INTERPRETATION OF THE LITIGATIVE UNIT}

While it was limiting the reach of original jurisdictional grants, the Supreme Court was promoting soinething seemingly contradictory: the packaging of an entire dispute into a single piece of litigation, notwithstanding that some portions of the case were not supported by imdependent bases of subject inatter jurisdiction. The Court instigated and supported this trend toward joining federal and nonfederal claims in two Inajor ways: by recognizing and expanding supplemental jurisdiction, ${ }^{81}$ and by promulgating the joinder provisions of the Federal Rules of Civil Procedure. ${ }^{82}$

\section{A. Supplemental Jurisdiction and the Joinder Rules: Confluence of Procedural and Constitutional Tests.}

The Supreme Court recognized in 1824 that a federal court may decide matters of state law in a federal question case. In Osborn v. Bank of the United States, ${ }^{83}$ Chief Justice Marshall observed that "[t]here is scarcely any case, every part of which depends on the constitution, laws, or treaties of the United States." 84 Because the federal court had jurisdiction over the entire case, it had power to determine incidental nonfederal substantive questions. ${ }^{85}$ In the early twentieth century, the Court upheld the exercise of supplemental jurisdiction over a separate nonfederal claim that was part of the same cause of action as a pending federal claim. ${ }^{86}$

80. See supra note $S$ and accompanying text.

81. See supra note 1.

82. FED. R. CIV. P. 13(a) (compulsory counterclaims); FED. R. CIv. P. 13(b) (permissive counterclaims); FED. R. Crv. P. 13(g) (cross-claims); FED. R. CrV. P. 13(h) (adding parties on counterclaim and cross-claim); FED. R. Crv. P. 14(a) (impleader claims; claims by third-party defendant against plaintiff; claims by plaintiff against third-party defendant); FED. R. Crv. P. 18 (joinder of claims and remedies); FED. R. CTv. P. 19 (joimder of parties needed for just adjudication); FED. R. CIV. P. 20 (permissive joinder of parties); FED. R. CIV. P. 22 (interpleader); FED. R. CrV. P. 24(a) (intervention of right); FED. R. CIV. P. 24(b) (permissive intervention).

83. 22 U.S. (9 Wheat.) 738 (1824).

84. Id. at 820 .

85. Id. at 823 .

86. Hurn v. Oursler, 289 U.S. 238, 246 (1933) (federal copyright infringement claim and state unfair competition claim held to be "two grounds in support of a single cause of action"); Siler $v$. 
In 1861, the Court expressly recognized supplemental jurisdiction over nonfederal claims joined to a pending case. In Freeman v. Howe, 87 the federal court had custody of property that was the center of dispute. Unless the Supreme Court allowed potentially affected absentees, whose joinder would have destroyed complete diversity, to intervene in the federal action, they might have been denied a forum in which to press their claims to the property. Using this implicit necessity as its justification, the Court upheld jurisdiction over such "ancillary and dependent [claims] ... without reference to the citizenship or residence of the parties." 88

Commentators universally characterize Freeman as a case in which supplemental jurisdiction was necessary to avoid a violation of due process; $^{89}$ if the Court had not allowed the intervenors to litigate in the federal court that held the disputed property, they would have been denied a hearing. But this reasoning assumes that the efficient packaging ought to take place in federal, and not state, court. Due process obviously does not compel this result. Indeed, due process could have been satisfied in Freeman-and the Strawbridge rule left unsullied-by dismissing the entire case under the doctrine of indispensable parties ${ }^{90}$ and allowing all parties to bitigate in state court.

The Court overlooked that option, however, and close instead to facilitate packaging in federal court, thereby implying that Strawbridge would be subordinated to the goal of inclusive packaging, at least as far as joined claims were concerned. In public-interest terms, this recognition of supplemental jurisdiction made the federal court a more efficient foruni for dispute resolution. If the Court had insisted on separate grounds of jurisdiction for each joimed claim, the litigants might have been forced to undertake duplicative litigation in state and federal court,

Louisville \& N. R.R., 213 U.S. 175, $192-93$ (1909) (federal claim of due process violation vested court with jurisdiction over state claim that statute did not empower commission to issue rates). See also Schenkier, Ensuring Access to Federal Courts: A Revised Rationale for Pendent Jurisdiction, 75 NW. U.L. REV. 245, 251-55 (1980) (discussing evolution of pendent jurisdiction to accommodate changing perceptions of federalism).

87. 65 U.S. (24 How.) 450 (1861).

88. Id. at $460-61$.

89. See, e.g., C. WRIGHT, supra note $25, \S 9$, at 29.

90. The intervenors could have been considered subject to compulsory joinder, since they could have been prejudiced had the suit gone forward without them. Because joinder would have destroyed diversity jurisdiction and because an alternative forum in state court was apparently available, the Court should have dismissed the case. See Shields v. Barrow, 58 U.S. (17 How.) 130, 139 (1855) (establishing indispensable parties doctrine). Supplemental jurisdiction has not been permitted in the indispensable parties situation. See Freer, supra note 2, at 1085-88. As currently formulated, the indispensable parties rule implicitly rejects suppleunental jurisdiction. See FED. R. CrV. P. 19(b) (joinder compelled only if it would not affect subject matter jurisdiction). 
an obviously undesirable result both to the litigants and to society.91

There is also an interest-group explanation for this recognition of suppleinental jurisdiction. If inclusive packaging were unavailable in federal court, many litigants would eschew tliat forum altogether and go to state court, where there are no such jurisdictional restrictions. Although the federal courts ought not be overburdened, undersubscription has costs as well. Failure to facilitate packaging through developinent of supplemental jurisdiction might liave left the federal courts underused, hearing only cases involving relatively few parties, where joinder would not violate Strawbridge. ${ }^{22}$ Such highly specialized courts might not be a tool of real utility to the bar ${ }^{93}$ and might not command great prestige. ${ }^{94}$ In interest-group terms, then, the federal judiciary's desire to maximize prestige might lead to an expansion of supplemental jurisdiction. Thus the public interest in efficient hitigation and interestgroup theory botli support some liberality in facilitating joinder.

The Court apparently expanded the availability of supplemental jurisdiction in Moore v. New York Cotton Exchange. 95 Moore permits federal courts to entertain a compulsory counterclaim, notwithstanding the absence of an independent jurisdictional basis. ${ }^{96}$ Moore did not speak of a "necessity" for ancillary jurisdiction, but einpliasized the close relationship between the plaintiff's claim and the counterclaim. ${ }^{97}$ Although an attentive reading of Moore does not disclose a conscious desire to expand

91. Multiple litigation imposes duplicative costs on society, which must pay for the additional jurors and court personnel. The party involved not only incurs more expense, but may risk collateral estoppel from the case that goes to judgment first. See Matasar, supra note 1, at 170.

92. Of course, federal question cases would still be litigated in federal court.

93. See R. PosNER, supra note 37, at 147-60. Perliaps this fear was greater at the time snppleinental jurisdiction was first recognized than it is today. It is interesting in this connection to compare the Supreme Court's concern in 1844 over the bar's dissatisfaction with the complete diversity rule of Strawbridge, see Louisville, C. \& C. R.R. v. Letson, 43 U.S. (2 How.) 497, 555 (1844), with the antidiversity sentiment expressed by some of today's leading federal judges, which prevails despite the bar's continued desire for diversity jurisdiction. See supra text accompanying notes 62-64.

94. See Landes \& Posner, supra note 74, at 369 (discussing relationship between power to create precedents and prestige).

95. 270 U.S. 593 (1926).

96. Id. at 610. The plaintiff's claim was based on federal antitrust laws, id. at 602 , while the couuterclaim was based on state law. Id. at 603 . Because the parties were not of diverse citizenship, there was no independent basis for jurisdiction over the counterclaim. Id. at 608 .

97. Indeed, the relationship between the two claims was so close that the failure of one would establish the other. $I d$. at 609-10. The two claims thus fit within the "logical dependence" test later used by the Supreme Court in Owen Equip. \& Erection Co. v. Kroger, 437 U.S. 365, 376 (1978) in discussing the proper circumstances for exercising supplemental jurisdiction. See infra notes 191-98 and accompanying text. Presumably, the Court could have based its decision on necessity, since failure to assert a compulsory connterclaim resnits in loss of the clain by "rule preclusion," which precludes a party from asserting a claim that could lave been asserted, but was not, in a compulsory joinder device. See C. WRIGHT, supra note $25, \S 79$, at 527. 
the availability of supplemental jurisdiction, ${ }^{98}$ commentators and the lower courts have consistently read the case as opening the door for the exercise of ancillary jurisdiction justified by efficiency or convenience. ${ }^{99}$

The Federal Rules of Civil Procedure, promulgated in 1938, 100 provided an enormous boost for packaging hitigation. The new joinder rules promoted an inclusive litigative unit based on transactional relationship; most of the rules permitted joinder of claims that arose from the "same transaction or occurrence" as the underlying action. ${ }^{101}$

By increasing the possibility that nonfederal claims would be joined in federal court, these rules heightened the tension between the restrictions on federal jurisdiction and the goal of packaging. ${ }^{102}$ The lower federal courts soon recognized, as the Supreme Court implicitly had in Freeman, that the efficacy of the joinder rules would be threatened were an independent basis of subject matter jurisdiction required for each claim joined. ${ }^{103}$ Inspired by Moore, the lower courts reevaluated and ultimately expanded the scope of supplemental jurisdiction to facilitate use of the Federal Rules. ${ }^{104}$

The result was a general confluence of the tests used for joinder and

98. The relationship between the original and the ancillary claims was so close as to require no doctrinal expansion. See supra note 94. See also 13 C. WRIGHT, A. MHLLER \& E. CoOpER, supra note $15, \S 3523$, at 94 ("The Supreme Court .. . gave very little explanation of why the federal court had jurisdiction to hear the counterclaim.").

99. See J. FRIEdentizal, M. KANE \& A. Miller, supra note 1, § 2.14, at 76; C. WRIGit, supra note 25, § 9, at 29-30; Champlin, Extension of Federal Subject Matter Jurisdiction: The Need for a Functional Approach, 26 WAYNE L. REv. 1437, 1450 n.76 (1980). At the very least, Moore implicitly rejected any notion that supplemental jurisdiction was limited to cases involving claims to a res in the possession of the federal court.

100. See 308 U.S. 651 (1938) (Federal Rules as originally promulgated by Supreme Court). For a brief discussion of the profound impact of the Federal Rules on packaging, see Freer, supra note 2, at 1065-67.

101. The following rules employed the transaction or occurrence test, or one clearly encompassed by it, in prescribing appropriate joinder: FED. R. CrV. P. 13(a) (compulsory counterclaims), FED. R. CIV. P. 13(g) (cross-claims), FED. R. Crv. P. 14(a) (impleader claims; claims by third-party defendant against plaintiff; claims by plaintiff against third-party defendant), FED. R. CrV. P. 14(c) (third-party claims in admiralty), FED. R. CrV. P. 20(a) (permissive party joinder), FED. R. CTV. P. 24(a)(2) (intervention of right).

102. See Freer, supra note 2, at 1067-72; Goldberg, The Influence of Procedural Rules on Federal Jurisdiction, 28 STAN. L. REV. 395, 416-21 (1976).

103. See Freer, supra note 2, at 1069-70; Goldberg, supra note 102, at 418-19.

104. This expansion raised a possible conflict with Rule 82 of the Federal Rules of Civil Procedure, which provides that the Federal Rules "shall not be construed to extend or limit the jurisdiction of the district courts of the United States." Professor Goldberg las concluded that Rule 82 is mandated by neither the Constitution nor the Rules Enabling Act, 28 U.S.C. $\S 2072$ (1982), but embodies a self-imposed policy of restraint that does not preclude consideration of procedural changes in formulating tests for supplemental jurisdiction. See Goldberg, supra note 102, at 432-43. But see 13 C. WRIGHT, A. MILLER \& E. COOPER, supra note 15, $\S 3523$, at 94 (Federal Rules have not broadened scope of supplemental jurisdiction, but have permitted greater opportunities for its invocation). 
for supplemental jurisdiction.10s For example, courts came to exercise ancillary jurisdiction over nonfederal claims that arose from the same transaction or occurrence as the underlying federal claim, thereby using the procedural jomder test as the jurisdictional norm. ${ }^{106}$ This confluence was not surprising, of course, since the joinder rules and supplemental jurisdiction shared the goals of achieving efficient packaging and avoiding duplicative litigation. ${ }^{107}$

\section{B. The Supreme Court's Imprimatur.}

The Supreme Court watched this jurisdictional expansion under the Federal Rules quietly. It made no comment until 1966, when it avidly embraced the trend in United Mine Workers v. Gibbs. ${ }^{108}$ In Gibbs the Court upheld the exercise of supplemental jurisdiction over a state law claim joined to a claim based on federal labor law. ${ }^{109}$ The case set the constitutional boundary for supplemental jurisdiction, holding that nonfederal claims could be heard if they were part of the same "case" as the jurisdiction-invoking claim. That issue was determined, inter alia, ${ }^{10}$ by whether the nonfederal claims and a substantial federal claim properly before the court arose from a "common nucleus of operative fact."11 The Court thus defined the constitutional term "case" in transactional terms; it expressly tied the propriety of supplennental jurisdiction to the factual commonality between nonfederal and federal claims, just as

105. 13 C. WRIGHT, A. MILLER \& E. COOPER, supra note 15, § 3523, at 95-96; Freer, supra note 2, at 1072; Goldberg, supra note 102, at 416.

106. See, eg., Schwab v. Erie L.R.R., 438 F.2d 62, 68-71 (3d Cir. 1971); Dery v. Wyler, 265 F.2d 804, 807 (2d Cir. 1959).

107. See, eg., Great Lakes Rubber Corp. v. Herbert Cooper Co., 286 F.2d 631, 633-34 (3d Cir. 1961) (noting that the tests for joinder of compulsory counterclaims and for supplemental jurisdiction "are the same because Rule 13(a) and the doctrine of ancillary jurisdiction are designed to abolish the same evil, viz., piecemeal litigation in the federal courts").

108. 383 U.S. 715 (1966).

109. Id. at $721-29$.

110. In addition to the requirement that the federal and nonfederal claims arise from a "comunon nucleus of operative fact," Gibbs requires that the federal issue be substantial and that the case be such that one pould normally expect to try the federal and nonfederal claims in a single proceeding. If these conditious are met, then the federal court has power to entertain the entire action, although certain discretionary factors may justify dismissal of the nonfederal claim. Id. at 726-27. Some commentators have noted that the language used by the Court suggests that the expectation of a unified trial and the common nucleus requirement are disjunctive, not conjunctive. See, e.g., Baker, Toward a Relaxed View of Federal Ancillary and Pendent Jurisdiction, 33 U. PrTT. L. REV. 759, 764-65 (1972); Matasar, supra note 1, at 123 n.93. Courts have not agreed, however, and have considered thein two separate requirements. See, eg., Ferguson v. Mobil Oil Corp., 443 F. Supp. 1334, 1340 (S.D.N.Y. 1978), aff'd, 607 F.2d 995 (2d Cir. 1979). Even as such, however, the factors rarely have independent significance. See Miller, Ancillary and Pendent Jurisdiction, 26 S. TEX. L.J. 1, 3 (1985).

111. Gibbs, 383 U.S. at 725. 
the lower courts had done in developing the confluence between the procedural and constitutional standards for joinder. ${ }^{112}$

Gibbs did not mandate that supplemental jurisdiction be exercised. The Court made a sharp distinction between constitutional power to exercise supplemental jurisdiction and the circumstances under which that power ought to be exercised. ${ }^{113}$ Under Gibbs, the trial judge has broad discretion to refuse to exercise supplemental jurisdiction, and should consider "judicial economy, convenience and fairness to litigants," "114 among other factors, ${ }^{115}$ in determining whether to hear a nonfederal claim. Initially, commentators believed that the discretion recognized in Gibbs was so broad that the case would result in less use of supplemental jurisdiction. ${ }^{116}$ In fact, of course, Gibbs has had the opposite effect.117

The Gibbs Court failed to mention at all whether Congress had sanctioned the exercise of supplemental jurisdiction, either in that case or generally. Indeed, in the century since Freeman, the Court had never addressed any statutory basis for its tremendous extension of supplemental jurisdiction. ${ }^{118} \mathrm{Gibbs}$ was the latest in this expansion, and it, like the others, purported to address only constitutional power to entertain nonfederal claims.

112. See supra notes $105-07$ and accompanying text.

113. Gibbs, 383 U.S. at 726.

114. Id.

115. These additional factors imclude such prudential limitations as "the likelihood of jury confusion in treating divergent legal theories of relief, that would justify separating state and federal claims for trial." Id. at 727. The Court also indicated that the trial judge has discretion to refuse to entertain a supplemental claim because of federalism concerns. Id. (supplemental jurisdiction should be rejected where "state issues substantially predominate" as to issues of proof, scope of the questions raised, or comprehensiveness of the remedy sought). See also Shapiro, Jurisdiction and Discretion, 60 N.Y.U. L. REv. 543, 559-60 (1985) (discussing discretion under supplemental jurisdiction doctrines).

116. See J. Friedenthal, M. KAiNe \& A. MiLleR, supra note 1, § 2.13, at 71-72; C. WRIGHT, supra note $25, \S 19$, at 106-07.

117. See J. FriedenthaL, M. KAINE \& A. Minler, supra note 1, § 2.13, at 71; Shakman, The New Pendent Jurisdiction of the Federal Courts, 20 STAN. L. REv. 262, 263 (1968). In some measure, this expansion is due to trial courts' failure to invoke the discretionary Gibbs factors to refuse to exercise supplemental jurisdiction. See J. FRIEDENTHAL, M. KANE \& A. MIIIER, supra note 1, $\$ 2.13$, at 72 ("IM]ost courts have exercised their discretion to hear a pendent claim if the [constitutional] power to do so is found to exist; only a few courts have used their discretion to dismiss pendent claims." (footnotes omitted)).

118. See C. WRIGHT, supra note $25, \S 19$, at 105.06; Cominent, Aldinger v. Howard and Pendent Jurisdiction, 77 CoLUM. L. REv. 127, 129-35 (1977). Those editions of leading treatises published shortly after Gibbs was decided discuss only the constitutional and discretionary standards, failing to raise the question of whether Congress had, or even should have, approved supplemental jurisdiction. See F. JAMES \& G. HAzA.RD, CIVIL ProcedurE § 12.5 (2d ed. 1977) (no mention of need for legislative authorization); C. WRIGHT, HANDBOOK ON THE LAW OF FEDERAL CoURTS $\S \S 9,19$ (2d ed. 1970) (same). 


\section{Tension with the Narrow Interpretation of Jurisdictional Grants: The Oxymoron of Common Law Subject Matter Jurisdiction.}

Compared with the cases discussed in Part I, Gibbs and its predecessors present a manifest paradox. On the one hand, the Supreme Court has construed the invocation of jurisdiction so narrowly that cases clearly within the federal courts' constitutional competence must be heard in state court. ${ }^{119}$ On the other hand, cases from Freeman to Gibbs demonstrate great eagerness to bring into federal court claims that do not meet the statutory requirements for invoking jurisdiction.

This contrast is all the more curious when we consider the perceived role of Congress. On the one hand, where Congress has provided a statutory basis mirroring the Constitution, the courts have not exercised power to the constitutional limit. On the other hand, the courts have extended supplemental jurisdiction to the constitutional limit without even mentioning a statutory basis.

Commentators have concluded that the supplemental jurisdiction developed in the cases culminating in Gibbs represented common law federal subject matter jurisdiction. ${ }^{120}$ If one accepts the traditionally held view, the Constitution requires that Congress prescribe the jurisdiction of the lower federal courts.121 Thus common law subject inatter jurisdiction is an oxymoron, and unless we conclude that the courts have been usurping jurisdictional power unconstitutionally for over a century, ${ }^{122}$ there must be a statutory basis for supplemental jurisdiction. Yet, as will be seen, Congress has never expressly addressed supplemental jurisdiction under the general jurisdictional statutes.

\section{Reconciling the NARROW AND tHe BROAD: A GeNERAI THEORY OF THE STATUTORY BASIS OF SUPPLEMENTAL JURISDICTION}

I propose that the two lines of authority are not inconsistent, but represent interpretations of separate portions of the jurisdictional statutes. The cases restricting original access to federal court construe those parts of the statutes pertaining to jurisdictional basis. In Strawbridge,

119. See supra notes $30-33$ and accompanying text.

120. See supra note 5 and accompanying text.

121. See supra notes $13-14$ and accompanying text.

122. Of course, the charge that a branch of government has been acting unconstitutionally is not to be made lightly. Nonetheless, such longstanding unconstitutional action can occur. For example, in Erie R.R. v. Tompkins, 304 U.S. 64 (1938), the Supreme Court concluded that its almost centurylong adherence to the doctrine of Swift v. Tyson, 41 U.S. (16 Pet.) 1 (1842), had been an unconstitutional usurpation of state power. Erie, 304 U.S. at 77-78. 
Chief Justice Marshall expressly limited the statutory phrase prescribing suit between a "citizen of the State where the suit is brought and a citizen of another State"; ${ }^{123}$ similarly, the Court's limiting interpretations of the quantum of federal material that must be involved to invoke federal question jurisdiction have been constructions of the statutory requirement that an action "arise[] under" federal law. ${ }^{124}$ The suppleinental jurisdiction cases, in contrast, interpret a different part of the jurisdictional statutes-the part pertaining to the scope of the "civil action" properly before the court. Acceptance of this distinction not only renders manifest the Supreme Court's confusion in later supplemental jurisdiction cases, but also debunks the myth that supplemental jurisdiction constitutes common law subject matter jurisdiction.

\section{A. The Scope of the Civil Action: Rejecting the Oxymoron of Common Law Subject Matter Jurisdiction.}

The Court's consistent failure even to refer to statutory authorization for suppleinental jurisdiction does not mean that such authorization is nonexistent. ${ }^{12 s}$ The entire tortuous exercise of narrowly construing the statutory language relating to jurisdictional basis was premised on an understanding of the difference between constitutional and statutory grants of jurisdiction. It is simply unthinkable that the Court would countenance an expansion of juriscliction by judicial fiat.

A more persuasive explanation for the omission is that no separate statutory standard for supplemental jurisdiction exists; instead, that standard is the same as the constitutional standard. ${ }^{126}$ In Gibbs, the Court held that the relationship between a state and a federal claim might be so close as to "permit[] the conclusion that the entire action before the court comprises but one constitutional 'case." "127 So, too, the relationship between the state and federal claim might be so close as to permit the conclusion that they comprise one statutory "civil action."128 In-

123. Strawbridge v. Curtiss, 7 U.S. (3 Cranch) 267, 267 (discussing Judiciary Act of 1789, § 11, 1 Stat. 73, 78). Although the statute has been changed to apply to actions "between citizens of different States," 28 U.S.C. $§ 1331$ (a)(1) (1982), it is clear that Strawbridge remains the definitive interpretation of the statutory language relating to the basis of original diversity jurisdiction. $R$. Casad \& P. Simon, Civil Procedure 189 (1984). See also C. Wright, supra note 25, \$24, at 42.

124. See supra text accompanying notes $27-29$.

125. See infra notes $127-43$ and accompanying text.

126. This theory explains how the Court's exercise of supplemental jurisdiction can be viewed as constitutional, but it does not explain why the Court has remained silent about the theoretical basis for the exercise of this jurisdiction. This silence is perplexing. See supra text accompanying notes 120-122.

127. United Mine Workers v. Gibbs, 383 U.S. 715, 725 (1966).

128. The diversity and general federal question statutes adopted the term "civil action" as the unit of litigation in 1940. See Act of Apr. 20, 1940, ch. 117, Pub. I. No. 76-463, 54 Stat. 143, 143. 
stead of representing an unconstitutional judicial grasp of jurisdiction, the supplemental jurisdiction cases may evince the Court's assumption that Congress approved of its right to define the scope of a civil action as well as its definition of that scope as coextensive with the constitutional standard. 129

It does seem clear that Congress delegated to the judiciary the task of defining "civil action"; it has never attempted itself to define the term, and could have expected that courts would be suited for the task. Congress has expressly delegated to the Supreme Court the power to promulgate the Federal Rules, ${ }^{130}$ which include, of course, the joinder rules by which the litigative unit is defined. These rules have always favored a liberal definition of that unit, ${ }^{131}$ and Congress has never exercised its statutory right to reject a joinder rule. ${ }^{132}$

Both the courts and Congress seem to have recognized Congress's acquiescence in the federal judiciary's power to define the statutory scope of "civil action" under the jurisdictional statutes. In amending the diversity and general federal question statutes in 1940 to adopt the term "civil action," Congress expressly intended to have the statutory language comport with that used by the Supreme Court in the Federal Rules. ${ }^{133}$ In 1969, the Court recognized that a Federal Rule could not, consistent with Rule $82,{ }^{134}$ purport to define one of the statutory terms relating to invocation of diversity jurisdiction. ${ }^{135}$ The Court said nothing, however,

As Professor Currie has demonstrated, "[a]lthough Gibbs did not similarly elaborate the statutory basis of pendent jurisdiction, the sole conceivable rationale is the same [as for constitutional propriety]." That is, the term "civil action" as used in the federal question statute "embraces state law claims sufficiently related to the federal." Currie, Pendent Parties, 45 U. CHr. L. REV. 753, 754 (1978). Cf. Shapiro, supra note 115, at 560 (supplemental jurisdiction "is, at most, implicit in a Iegislative grant of jurisdiction").

From 1875 until 1980, the general federal question statute gave district courts jurisdiction over "suits of a civil nature" or "civil actions" in which "the matter in dispute exceeds [the statutory requirement] and aris[es] under [federal law]." See, e.g., Act of Mar. 3, 1887, § 1, 24 Stat. 552. In 1980, Congress amended the statute for the sole purpose of deleting the amount-in-controversy requirement. Act of Dec. 1, 1980, $94 \mathrm{Stat}$. 2369. The result is a provision lacking separate reference to subject matter basis and litigative unit, granting jurisdiction over "civil actions arising under [federal law]." Congress gave no indication that this amendment was intended to affect supplemental jurisdiction.

129. See infra notes $133-36$ and accoupanying text.

130. 28 U.S.C. § 2072 (1982).

131. See supra notes $100-07$ and accompanying text.

132. 28 U.S.C. $\$ 2072$ (1982) provides that Congress has power to reject rules promulgated by the Supreme Court. See generally C. WRIGHT, supra note 25, §62, at $402-08$ (describing development and history of the Federal Rules of Civil Procedure).

133. See supra note 125. Thus Congress expressly adopted the language used by the Supreme Court in the Federal Rules to define the hitigative unit.

134. See supra note 104.

135. Snyder v. Harris, 394 U.S. 332, 339 (1969). 
that would limit the judiciary's power to define the scope of the litigative unit.

Thus, both the structure of the jurisdictional statutes (providing for power over a "civil action" in a phrase separate from the language relating to the jurisdictional basis) and the grant of rulenraking power support the conclusion that Congress delegated to the federal courts authority to define the scope of the civil action. Both the transactional test of the Federal Rules and the Court's failure to mention a separate statutory standard in Gibbs suggest that the scope of the civil action is coextensive with the scope of the constitutional "case."136

One can reasonably conclude that Congress lias embraced the Court's equation of the statutory and constitutional standards for the scope of an action. Congress reenacted the diversity statute ${ }^{137}$ (and enacted for the first time the general federal question statute ${ }^{138}$ ) after Freeman without any comment on that case's recognition of supplemental jurisdiction. It reenacted and extended the coverage of both statutes after Moore without any comment on that case. ${ }^{139}$ It again reenacted without comment both statutes after the lower courts' expansion of supplemental jurisdiction to match the Federal Rules, ${ }^{140}$ and it amended the federal question statute after Gibbs without voicing any displeasure with that case's liberal statement of suppleniental jurisdiction. ${ }^{141}$ Using the traditional canon of statutory construction invoked in the cases restricting original federal court jurisdiction, ${ }^{142}$ Congress's failnre to disapprove of the judiciary's century-long expansion reflects its approval of a broad statutory view of the proper litigative unit. ${ }^{143}$

\section{B. The Resulting Theory.}

This recognition of a statutory basis for supplemental jurisdiction is iniportant for purposes of reconciling the two lines of cases; each line relates to a separate statutory provision embodying different policies. Keeping these separate bases and policies in mind helps to abate the ten-

136. See supra text accompanying notes 128-29.

137. Act of Mar. 3, 1875, ch. $137, \S 1,18$ Stat. 470,470 (pt. 3).

138. Id. $\S \S 2-3,18$ Stat. at $470-71$.

139. Act of Apr. 20, 1940, ch. 11\%, 54 Stat. 143.

140. Act of July 25, 1958, Pub. L. No. 85-554, § 1 (federal question), § 2 (diversity), 72 Stat. 415, 415; Act of Aug. 14, 1964, Pub. L. No. 88-439, § 1 (diversity), 78 Stat. 445, 445; Act of Oct. 21, 1976, Pub. L. No. 94-583, § 2 (federal question), 33 (diversity), 90 Stat. 2891, 2891.

141. Act of Dec. 1, 1980, Pub. L. No. 96-486, § 2(a), 94 Stat. 2369, 2369-70.

142. See supra text accompanying notes $41-42$.

143. But see supra text accompanying notes $43-44$ (noting that the traditional canon may not reflect any actual congressional imtent to adopt the judicial precedent by means of statutory reenactment). 
sion between the lines. All too often, however, courts misconstrue the task before them because of a failure to recognize the dual sets of interests involved.

Courts must address the restrictive line of authority first, to determine whether the claims originally stated, and the parties originally joined, satisfy one of the narrow bases for invoking jurisdiction. If they do, jurisdiction attaches, because the court has before it, for example, a "matter in controversy . . . between . . . citizens of different states."144 Then, as a separate, second endeavor, the court may flesh out the proper scope of the entire civil action surrounding the jurisdiction-invoking claim. The Federal Rules and the Gibbs test define that scope in terms of constitutional (and, impliedly, statutory) power and the proper exercise of discretion. ${ }^{145}$

This approach respects the policies underlying the respective lines of authority and assumes that a federal court acts within its power in defining the scope of the action before it. Thus, each line of authority operates where it is supposed to: the narrow line restricts invocation of jurisdiction, and the broad line promotes packaging.

This approach ensures that the policies underlying one line do not harm tliose supporting the other. For example, a court will not address supplemental jurisdiction until the restrictive rules for invoking jurisdiction are satisfied. Thus the desire for efficient packaging will not threaten the restrictions on invocation of jurisdiction. Similarly, the cases relating to invocation of jurisdiction have no bearing on supplemental jurisdiction; applying them there would thwart the policies supporting that doctrine. Thus the separate parts of the statutes, and their case law, slould be kept separate. 146

Interestingly, although the federal courts failed to discuss any statutory basis for suppleinental jurisdiction, their treatment of supplemental jurisdiction until recently was remarkably consistent with the model I have set forth. Until the mid-1970's, supplemental jurisdiction had developed neatly. With striking uniformity, tlie federal courts exercised ju-

144. 28 U.S.C. $\S 1332(a)(1)$ (1982).

145. The implicit statutory adoption of Gibbs, see supra text accompanying note 141, carries with it that case's discretionary factors, which allow the trial judge to weigh the relative benefits of packaging against other considerations. See supra note 115 and accompanying text.

146. Of course, Congress retains the power to restrict supplemental jurisdiction. But it has never done so. Indeed, it has legislated regarding supplemental jurisdiction only once. See 28 U.S.C. $\S 1338(b)$ (1982) (jurisdiction for action asserting a claim of unfair competition when joined with a substantial and related claim under the copyright, patent, plant variety protection, or trademark laws). Congress does not appear to have addressed the issue expressly or implicitly on any other occasion. If Congress wants to alter the status quo by rejecting the courts' equation of the statutory and constitutional standards for supplemental jurisdiction, it should do so by means of express legislation limiting supplemental jurisdiction. 
risdiction over claims satisfying the transaction-based constitutional test. ${ }^{147}$ They seemed to assume that Congress approved of their actions, almost implying a presumption in favor of applying the Gibbs test for supplemental jurisdiction. ${ }^{148}$ The result was workable and convenient, since the procedural propriety of most joinder devices is coextensive with the constitutional (and implied statutory) test. It was also efficient, facilitating the inclusive packaging of disputes and avoiding multiple litigation. ${ }^{149}$

Until the mid-1970's, the lower federal courts disagreed sharply on the availability of supplemental jurisdiction in only two types of cases: those involving "pendent parties"150 and those involving claims by the

147. Federal courts have for some time routinely exercised supplemental jurisdiction over compulsory counterclaims, see Great Lakes Rubber Corp. v. Herbert Cooper Co., 286 F.2d 631, 633 (3d Cir. 1961); third-party impleader claims, see Schwab v. Erie L.R.R., 438 F.2d 62, 68-72 (3d Cir. 1971); crossclaims, see Scott v. Fancher, 369 F.2d 842, 844 (5th Cir. 1969); claims of intervention as of right, see Atlantis Dev. Corp. v. United States, 379 F.2d 818, 822-25 (5th Cir. 1967); and claims by a third-party defendant against the original plaiutiff. See Revere Copper \& Brass Inc. v. Aetna Casualty \& Sur. Co., 426 F.2d 709, 714-16 (5th Cir. 1970). See generally 13 C. WRIGHT, A. MILIER \& E. COOPER, supra note $15, \S 3523$ (discussing ancillary jurisdiction).

148. Analogously, the Supreme Court did not mention a statutory basis for supplemental jurisdiction in any of its opinions from Osborn through Gibbs. See Comment, supra note 118, at 129-40. It may bc argued that Osborm implicitly resolved the question of statutory authorization; later cases, however, reject this notion. Id. at 130 n.23.

149. See J. Friedenthal, M. KAANE \& A. MirLER, supra note $1, \S 6.1$, at 313 (efficiency of packaging); 3A. J. MOORE \& J. LuCAS, MOORE's FedERAL PRACTICE, fl 18.02, at 18-6 (2d ed. 1986) (same).

150. See C. Wrighr, supra note $25, \S 19$, at $107-08$ ("IT]he Second Circuit led the way in holding that pendent jurisdiction would allow taking jurisdiction of a state claim against one party if it were related closely enough to a federal claim against another party, even though there was no independent jurisdictional base for the state claim."). These holdings imply, of course, that the court need not have an independent basis of jurisdiction over original claims against each defendant. See, e.g., Leather's Best, Inc. v. S.S. Mormaclynx, 451 F.2d 800, 809-10 (2d Cir. 1971); Astor-Honor, Inc. v. Grosset \& Dunlap, Inc., 441 F.2d 627, $629-30$ (2d Cir. 1971). Most courts that addressed the question approved of pendent party jurisdiction. See, e.g., Bowers v. Moreno, 520 F.2d 843, 846-48 (1st Cir. 1975); Florida E. Coast Ry. v. United States, 519 F.2d 1184, 1193-97 (5th Cir. 1975); Curtis v. Everette, 489 F.2d 516, 519-20 (3d Cir. 1973), cert. denied, 416 U.S. 995 (1974); Schulman v. Huck Finn, Inc., 472 F.2d 864, 866-67 (8th Cir. 1973). Commeutators also approved of the coucept. See, eg., Currie, supra note 128, at 766; Fortune, Pendent Jurisdiction-the Problem of "Pendenting Parties," 34 U. PrTT. L. Rev. 1, 21 (1972).

The United States Court of Appeals for the Ninth Circuit, however, has refused to recognize the doctrine. See, e.g., Ayala v. United States, 550 F.2d 1196 (9th Cir. 1977), cert dismissed, 435 U.S. 982 (1978); Moor v. Madigan, 458 F.2d 1217 (9th Cir. 1972), aff'd in part, rev'd in part sub nom. Moor v. County of Alameda, 411 U.S. 693 (1973). These opinions are based on a conclusory stateneent from Hymer v. Chai, 407 F.2d 136 (9th Cir. 1969), which dealt only with amount in controversy. See Currie, supra note 128, at 754-55.

The Supreme Court finally answered some questions concerning pendent party jurisdiction, at least in the context of a section 1983 civil rights case, in Aldinger v. Howard, 427 U.S. 1 (1970). See generally Infra text accompanying notes 157-76. 
plaintiff against a nondiverse third-party defendant. ${ }^{151}$ The split of authority mirrored confusion about how to approach these cases. The Supreme Court addressed both situations in the 1970's and only compounded the confusion. Because the Court had never recognized a statutory grant of power to exercise supplemental jurisdiction apart from the language relating to jurisdictional basis, it failed to appreciate the different purposes and policies of the two lines of authority. Like a ship without a rudder, the Court sailed aimlessly, and proceeded on the absurd conviction that the judiciary could, notwithstanding the absence of legislative consideration of the issue, divine a legislative intent to preclude supplemental jurisdiction.

\section{The 1970's AND tHe SudDEN APPEARANCE OF LEGISLATIVE INTENT}

In the mid-1970's, the Supreme Court addressed two cases involving the questions of supplemental jurisdiction that had divided the lower courts. In deciding them, the Court failed to identify a statutory basis for the principled resolution of supplemental jurisdiction questions, sanctioning instead an ad hoc search for legislative intent that has merely led to confusion. As I will now show, adopting the principled approach I propose would resolve the problems and eliminate the confusion.

\section{A. Pendent Parties.}

1. Defining the Task: The Principled Approach. The typical pendent party case involves the assertion of a federal question claim against one defendant joined with a closely related state claim against a different, nondiverse, defendant. ${ }^{152}$ As to this second defendant, there is neither federal question nor diversity jurisdiction. Nonetheless, the close factual relationship between the two claims might satisfy Gibbs. ${ }^{153}$ To those courts that reject supplemental jurisdiction in such circumstances, this

151. The majority of the cases held that there was no ancillary jurisdiction over such claims. See, e.g., Kenrose Mfg. Co. v. Fred Whitaker Co., 512 F.2d 890 (4th Cir. 1972). A substantial minority reached the opposite conclusion. See, eg., Morgan v. Serro Travel Trailer Co., 69 F.R.D. 697 (D. Kan. 1975). The Supreme Court resolved the dispute, at least in the diversity jurisdiction context, in Owen Equip. \& Erection Co. v. Kroger, 437 U.S. 365 (1977). See generally infra text accompanying notes 183-213.

152. See J. FRIEDENTHAL, M. KANE \& A. MmLER, supra note 1, § 2.13, at 73 (arguably the most justifiable application of pendent party jurisdiction is in precisely such situations); see also Fortune, supra note 150, at 21 (courts should not hesitate to exercise jurisdiction over a state claim against one defendant that shares a common factual background with a substantial federal claim against a codefendant).

153. The Gibbs test embodies the implied statutory standard as well as the constitutional limit for supplemental jurisdiction. See supra text accompanying notes 137-43. 
case represents a crossroads between the two lines of authority discussed above. To them, the liberality of the supplemental jurisdiction line of authority threatens at this point to overwhelm the narrow restrictions on invoking original jurisdiction.

The seriousness of the problem depends on the perspective one takes when attacking the pendent party problem. One who sees the case as presenting a supplemental jurisdiction issue would first consider wlietler the court's jurisdiction has been invoked by satisfaction of the restrictive line of authority. Presumably, the federal question as to the first defendant suffices for original jurisdiction, and the remaining question is whetlier the joined matter concerning the second defendant satisfies the procedural rules and Gibbs.

On tle other hand, one who sees the case as presenting a problem of original joinder is troubled by the fact that pendent party jurisdiction allows tlie claim against the second defendant into federal court even though one of the restrictive lines of authority for invoking jurisdiction is not satisfied. Here, it may be more difficult to conclude that the original joinder against the pendent defendant is merely part of the process of fleshing out tle scope of the civil action; it can as easily be seen as part of the process of invoking the court's original jurisdiction.

The unease surrounding pendent parties stems from a failure to appreciate tlie difference between these two perspectives and to assess critically which one is implicated in the case. The pendent party resultexercising jurisdiction over one against whom no federal claim is asserted-creates a serious problem only if one concludes that there is a statutory requirement that an independent basis of original jurisdiction exist over the claims asserted against each defendant.

Whether an independent basis of jurisdiction over each defendant is required depends on the statute involved and its requirements for invoking original jurisdiction. The restrictive interpretations of tle diversity statute do require satisfaction of the original basis of jurisdiction as to all original defendants. Strawbridge demands that all original plaintiffs be of diverse citizenship from all original defendants; it thus prohibits a plaintiff froin suing a diverse defendant and claiming pendent party jurisdiction over a nondiverse codefendant. ${ }^{154}$ The general federal question

154. This interpretation is consistent with Supreme Court precedent in the class action context denying aggregation and requiring that each member of a plaintiff class satisfy the statutory amountin-controversy requirement. See Zahn v. International Paper Co., 414 U.S. 291, 301 (1973); Snyder v. Harris, 394 U.S. 332, 338 (1969); see also Bratton, Pendent Jurisdiction in Diversity Cases-Some Doubts, 11 San Diego L. Rev. 296, 322-23 (1974); Note, Federal Pendent Party Jurisdiction and United Mine Workers v. Gibbs-Federal Question and Diversity Cases, 62 VA. L. REv. 194, 231-36 (1970). 
statute, in contrast, does not require an independent basis of jurisdiction over each original defendant. ${ }^{155}$ This difference stems, of course, from the character of the jurisdictional basis involved: federal question jurisdiction centers on substance, while diversity jurisdiction centers on parties.

Accordingly, in a diversity case involving a pendent party problem, the court would not reach a supplemental jurisdiction inquiry, since the requirements for invoking jurisdiction would not be satisfied. But where original jurisdiction is based on the general federal question statute, the pendent party case will present a supplemental jurisdiction problem, and the resolution of that problein will depend on whether joinder satisfies the joinder rules and the Gibbs constitutional (and implied statutory) standards for supplemental jurisdiction. Because Congress has not addressed the pendent party issue under the general federal question statute, congressional approval of supplemental jurisdiction should be presumed.

In Aldinger v. Howard, 156 the Supreine Court faced the pendent party issue under a specific federal question statute. Unfortunately, although Congress had not definitively addressed the question of supplemental jurisdiction in the context of that statute, the Court concluded that the legislature intended to preclude supplemental jurisdiction.

\section{Aldinger v. Howard.}

a. The presumption. In Aldinger, the plaintiff asserted a civil rights claim under section $1983^{157}$ against a county official who had discharged her because she allegedly had been living with her boyfriend. She jomed a state law claim against the county itself. The county could not have been sued under diversity jurisdiction because it and the plaintiff were cocitizens; it could not have been sued under section 1983 because that statute, as then interpreted by the Supreme Court, did not allow actions against municipalities. ${ }^{158}$ The Court rejected supplemental jurisdiction over the county, relying on what the Court felt was the "clear Congressional intent" of section 1983 that municipalities not be

155. See supra note 150.

156. 427 U.S. 1 (1976).

157. 42 U.S.C: $\S 1983$ (1982), which derives from section 1 of the Civil Rights Act of 1871, seeks to redress deprivations of constitutional rights. Its jurisdictional statute is 28 U.S.C. § 1343(a)(3)-(4) (1982).

158. See Monroe v. Pape, 365 U.S. 167, 187-92 (1961) (city not "person" for purposes of section 1983), overruled, Monell v. Department of Social Servs., 436 U.S. 658 (1978); infra note 166. 
sued in federal court. ${ }^{159}$

The Court expressly limited the holding in Aldinger to the pendent party situation in a section 1983 case. ${ }^{160}$ Nonetheless, the case is important because it expressly recognizes that Congress inust authorize suppleinental jurisdiction and implicitly rebuts the notion of common law subject matter jurisdiction. ${ }^{161}$ The Court's treatment of congressional authorization is odd, however. The case implicitly establishes a presumption that supplemental jurisdiction will be available unless Congress has negated it in some way. ${ }^{162}$

Although the Court's approach seems consistent with my proposal, there is one glaring difference. The Court seems willing to presume congressional approval of supplemental jurisdiction, but it has never identified the source of that legislative grant. This oversight leads the Court to overlook the fact thiat supplemental jurisdiction is part of the statutorily sanctioned process by which the scope of the civil action is fleshed out. This will lead, in turn, to a failure to protect the policies underlying supplenental jurisdiction. Before addressing these points, it is worth noting how ephemeral the Court's presumption is.

b. Rebutting the presumption: seeking what does not exist. The Court eviscerated its presumption by allowing rebuttal in the absence of any ineaningful indication of congressional disapproval of supplemental jurisdiction. Section 1983 said nothing about supplemental jurisdiction; the legislative history was at best inconclusive. ${ }^{163}$ In such a case, it is absurd to ponder a congressional intent to preclude supplemental jurisdiction. Indeed, the conclusion is especially ludicrous im Aldinger because pendent party jurisdiction had not even been recognized when

159. In the majority's view, the legislative history demonstrated that Congress intended to preclude subjecting mumicipal bodies to suit in federal court on any jurisdictional basis. Aldinger, 427 U.S. at 16-17. This intent constituted implied rejection of supplemental jurisdiction. Id. at 19.

160. Id. at 18 .

161. Id. at 15-16. The statutory issue bore discussion in Aldinger because there was a debate over whether supplemental jurisdiction was allowed under the statute in question. The Court distinguished the Gibbs situation, where the Court could appropriately fashion its own rules of supplemental jurisdiction over nonfederal claims or questions in the face of congressional silence on those issues, from the Aldinger situation, where Congress had addressed the propriety of jurisdiction over certain parties, thus leaving the Court less discretion. Id. at 15-16.

162. Id. at 18. See Schenkier, supra note 86, at 257-60; see generally Comment, supra note 118, at 140-42 (1977) (approving the Aldinger rule that jurisdictional statutes should be construed as granting pendent jurisdiction unless they negate it, but recognizing uncertainty as to what constitutes congressional negation).

163. See CoNG. GloBe, 42d Cong, 1st Sess. 704-804 (1871) (federal court may enforce state claims against local governments "under the ordinary restrictions as to jurisdiction"). For a detailed discussion of the legislative history, see Aldinger, 427 U.S. at 23-30 (Brennan, J., dissenting). See also Currie, The Supreme Court and Federal Jurisdiction: 1975 Term, 1976 SUP. CT. REV. 183, 197 (criticizing conclusion drawn in Aldinger from legislative history as "a glaring non sequitur"). 
Congress enacted section $1983 .{ }^{164}$ How, then, could Congress have intended to preclude its use?

By authorizing a search for legislative intent on an issue Congress never considered, the Aldinger Court invited all federal courts to speclilate, to hunt for some fictive intent relating to supplemental jurisdiction. ${ }^{165}$ Ironically, this practice leaves the ultimate decision not to the legislature-where it concededly belongs-but to the courts. This is exactly the result the Court ostensibly wanted to avoid. Indeed, Aldinger should be an especially good lesson about avoiding judicial inquiry into the nonexistent. Just two years after deciding the case, the Court overruled its earlier interpretation of legislative intent and lreld inunicipalities amenable to suit under section 1983.166

There is a more basic flaw in the Court's treatinent of this fictive legislative intent to preclude supplemental jurisdiction. The Court erred in looking for congressional intent in the absence of congressional action. As Professor Mayton and others have shown, the Constitution embodies a bias against new legislation. ${ }^{167}$ The framers purposefully made the pas-

164. See Comment, supra note 118 , at $145-46$.

165. See, eg., Kiss v. Tamarac Utils., Inc., 463 F. Supp. 951, 953.54 (S.D. Fla. 1978) (seeking evidence of congressional intent regarding pendent party jurisdiction under Title VII of the Civil Rights Act of 1964); Maltais v. United States, 439 F. Supp. 540, 547 (N.D.N.Y. 1977) (seeking evidence of congressional intent regarding pendent party jurisdiction under the Federal Tort Claims Act and its jurisdictional statute).

166. In Monell v. Department of Social Servs., 436 U.S. 658, 690-91 (1978), the Court looked again at the legislative history of section 1983 and concluded that its previous reading of that history had been erroneous. C. WRIGHr, supra note $25, \S 22 \mathrm{~A}$, at 121 . Monell held that a municipal body is a "person" under section 1983, at least insofar as the gravamen of the claim against it is that the body's implenentation of an official policy or custon worked a deprivation of civil rights. Monell, 436 U.S. at 690-91. Justice Brennan, dissenting in Aldinger, had based his conclusion that counties were "persons" on a reading of some of the same portions of legislative history that were later relied on in Monell. Compare Aldinger, 427 U.S. at 26-29 (Brennan, J., dissenting) (quoting portions of floor debates on predecessor of section 1983) with Monell, 436 U.S. at 680 (relying on the same debates). But in Aldinger, the Court saw the legislative history relied on by Justice Brennan as irrelevant to the question of pendent party jurisdiction. Aldinger, 427 U.S. at 17 n.12. Thus Aldinger provided no clue that such a major slift in the reading of that history might be forthcoming. These divergent interpretations, within two years of each other, of the legislative history of a statute inore than a century old, suggest the folly of the Court's reliance in Aldinger on the clear legislative intent of the statute.

167. See Mayton, The Possibilities of Collective Choice: Arrow's Theorem, Article I, and the Delegation of Legislative Power to Administrative Agencies, 1986 DukE I.J. 948 (Article I imposes decision costs and checks on legislative process in order to restrain instability of the law); see also INS v. Chadha, 462 U.S. 919, 945-51 (1983) (framers of the Constitutiou drafted presentunent and bicameral requirements with great precision in order to circunscribe congressional power to enact new legislation); C. BlaCK, StruCture aNd Relationship in CONSTITUTIONAL LAW 82 (1969) ("[T] he Constitution provides one way, and one way only-and that is a way hedged with careful safeguards-for Congress to express the national purpose and will."). 
sage of new laws difficult by requiring majority votes in each House ${ }^{168}$ and by providing for presidential veto. ${ }^{169}$ The Court's conclusion that Congress can rule without satisfying those constitutionally imposed requirements-by merely "intending" soine result-presumes Congress has more power than it does.

c. Confusing the narrow and the broad. The Court asserted that pendent party jurisdiction is, as a general matter, more difficult to sustain than other forms of supplemental jurisdiction because it involves proceeding against a defendant as to whom no federal claim is asserted.170 There is no basis for this general conclusion, which reflects fundainental confusion of the respective inquiries to be made. It presupposes that the jurisdictional statutes require an independent basis of jurisdiction as to each original defendant. As discussed above, however, only the diversity statute so requires. ${ }^{171}$

The Court added further confusion by positing a hypothetical example of an appropriate case for pendent party jurisdiction. The Court indicated that it would favor such jurisdiction when the jurisdiction-invoking claim was within the exclusive jurisdiction of the federal courts. In such a case, the Court implied, it could presume that Congress intended broad packaging, since otherwise the plaintiff would have to split the case into two actions. ${ }^{172}$

But this example is meaningless. First, the Court contradicts itself. Earlier, it indicated that the relevant statutory imquiry was whether Congress had precluded jurisdiction. ${ }^{173}$ With the example concerning exclusive jurisdiction, lowever, it approves supplemental jurisdiction because Congress lias affirmatively embraced it. Second, the Court makes the fundamentally erroneous assumption that congressional intent (even if discermible and relevant) regarding one statute says anything at all about how a different statute should be interpreted. Indeed, the mere fact that Congress has statutorily granted exclusive original jurisdiction regarding a certain type of case may say nothing about its intent as to supplemeutal jurisdiction under that statute; it certainly says nothing about congres-

168. U.S. CoNST. art. I, § 7. This requirement both "assures that the legislative power [will] be exercised only after opportunity for full study and debate in separate settings," Chadha, 462 U.S. at 951, and decreases the likelihood that it will be exercised at all. M. IRISH \& J. Prothro, ThE Politics of AMERICAN DEMOcracy 386 (1959).

169. U.S. CoNST. art. I, $\S 7$, cl. 3. The requirement of a two-thirds vote in the Senate to override a presidential veto may discourage measures that will inspire significant opposition.

170. Aldinger; 427 U.S. at 18.

171. See supra text accompanying notes 154-55.

172. Aldinger, 427 U.S. at 18.

173. Id. at $16-17$. 
sional intent regarding supplemental jurisdiction under an entirely different statute.

After all, the desire to package efficiently is the same regardless of whether the jurisdiction-invoking claim is within exclusive federal jurisdiction. And there may be a strong policy interest in having even a nonexclusive federal question heard in federal court. In Aldinger, for example, the plaintiff was forced to proceed against the county in state court. ${ }^{174}$ Thus, she either had to (1) split her action between state court and federal court, (2) assert all claims in state court, thereby abandoning a federal forum for her federal claim, or (3) proceed in federal court and abandon the claim against the county altogether. Obviously, she would have preferred to assert federal rights in a federal forum, especially if she feared bias in the state courts. And although the legislative history of section 1983 was debated on some counts, ${ }^{175}$ one thing is clear: Congress wanted these claims heard in federal court if the plaintiff so desired. ${ }^{176}$ Thus, by limiting the packaging presumption to cases involving exclusive federal jurisdiction, the Court forced the abandonment of important federal claims to state courts.

In sum, Aldinger gives no consistent analysis. It purports to presume congressional approval for supplemental jurisdiction but fails to indicate the source of such grant. Its nervousness over not having an independent federal claim as to each defendant demonstrates a tendency to confuse restrictions on original jurisdiction with restrictions on supplemental jurisdiction. Unable to extract itself from this confusion, the Court attempted to resolve matters by a searcli for fictive intent.

\section{B. Plaintiff's Claim Against a Nondiverse Third-Party Defendant.}

1. The Principled Result. The second situation that caused serious disagreement among the lower courts after Gibbs was the assertion of a claim under Rule 14(a) ${ }^{177}$ by a plaintiff against a nondiverse third-party defendant in a diversity case. There are two prerequisites for bringing such claims. First, one of the original defendants must implead the third party; this jomder is proper only if the third party is allegedly liable to

174. This conclusion assumes that Monell had not been decided before Ms. Aldinger's claim went to trial. See supra note 166.

175. See supra notes $163,166$.

176. See CONG. GLOBE, 42d Cong., 1st Sess. 476 (1871) (remarks of Sen. Dawes); see also Monroe v. Pape, 365 U.S. 167, 173-80 (1961) ("[O]ne reason the legislation was passed was to afford a federal right in federal courts...."); Chevigny, Section 1983 Jurisdiction: A Reply, 83 HARV. L. REv. 1352, 1356-61 (1970) (presenting policy arguments for providing federal forum).

177. FED. R. Crv. P. 14(a) ("The plaintiff may assert any claim against the third-party defendant arising out of the transaction or occurrence that is the subject matter of the plaintifi's claims against the third-party plaintiff...."). 
the defendant for indemnity or contribution relating to the plaintiff's underlying claim. ${ }^{178}$ Second, the plaintiff's claim against the third party must "aris[e] from the saine transaction or occurrence" as the underlying action. 179 This claim joinder requirement obviously satisfies the Gibbs test for supplemental jurisdiction. ${ }^{180}$

Using the principled approach proposed above, the first inquiry is whether the restrictive statutory interpretation for invocation of original jurisdiction is satisfied. It will be, of course, if there is complete diversity between the original plaintiff and the original defendant and the amount in controversy exceeds $\$ 10,000$. The second step is to flesh out the scope of the civil action through the joinder rules and supplemental jurisdiction in accordance with Gibbs. The plaintiff's claim here is clearly a matter of subsequent joinder, not original invocation of jurisdiction. It thus does not implicate Strawbridge, and should be asserted under suppleinental jurisdiction, since it satisfies both the Federal Rules and Gibbs. And because Congress lias never satisfactorily addressed the general availability of supplemental jurisdiction either under the diversity statute or with regard to a Rule 14(a) claim by a plaintif against a nondiverse thirdparty defendant, there is no basis for inquiring whether Congress has precluded the exercise of supplemental jurisdiction. ${ }^{181}$

Nonetheless, the Court concluded in Owen Equipment \& Erection Co. v. Kroger that Congress had intended to preclude supplemental jurisdiction over Rule 14(a) claims by a plaintiff against a nondiverse thirdparty defendant. ${ }^{182}$ It did so only through a blatant mischaracterization of the issue, which allowed it to import into the supplemental jurisdiction inquiry restrictions that are appropriate only with regard to the invocation of original jurisdiction.

178. Id. The rule provides that any "defending party" may assert a claim against one "not a party to the action who is or may be liable to him for all or part of the plaintiff's claim against him." This impleader claim may be asserted even when state law requires judgment against the defendant as a prerequisite to a suit for indemnity or contribution. See, eg., Holzhauser v. Container Corp. of Am., 93 F.R.D. 837, 839 (W.D. Ark. 1982). It is a prerequisite to the plaintiff's assertion of a claim against the newly joined third-party defendant and the third-party defendant's assertion of a claim against the plaintiff. FED. R. Civ. P. 14(a). See generally J. FrIEDENTHAI, M. KANE \& A. MiLLER, supra note $1, \S 6.9$, at 360-65; Freer, supra note 2, at 1089-93.

179. See supra note 177.

180. See supra note 153 .

181. See supra text accompanying notes 137-45; see also Berch, The Erection of a Barrier Against Assertion of Ancillary Claims: An Examination of Owen Equipment \& Erection Co. v. Kroger, 1979 ARIZ. ST. L.J. 253, 253 \& n.1 (no statutory probibition discernible).

182. Owen Equip. \& Erection Co. v. Kroger, 437 U.S. 365, 377 (1978). 


\section{Owen Equipment \& Erection Co. v. Kroger.}

a. The case. In Kroger, the Court was willing to assume the obvious fact that a Rule 14(a) claim by a plaintiff against a nondiverse thirdparty defendant satisfies the constitutional test for supplemental jurisdiction. ${ }^{183}$ Nonetheless it rejected-imdeed, absolutely precluded-use of supplemental jurisdiction over such claims. ${ }^{184}$ The holding was entirely statutory. ${ }^{185}$

In the Court's view, the plaintiff was attempting to assert state claims against both diverse and nondiverse parties. If this had been attempted in an original complaint, the joinder would have violated Strawbridge. Therefore, a per se rule of dismissal was dictated; the plaintiff was attempting by indirection what could not be accomplished directly. ${ }^{186}$ This reasoning presents profound confusion regarding the difference between invoking original jurisdiction and using supplemental jurisdiction to facilitate packaging.

b. Congressional intent: construing the nonexistent. The Court's treatinent of legislative intent in Kroger focuses on a series of irrelevant factors, such as defendant-initiation and logical dependence, which are to be weighed in some undefined ad hoc manner in order to ascertain whether Congress imphicitly intended to preclude a particular exercise of supplemental jurisdiction. ${ }^{187}$

183. Id. at 371-72 \& n.10. The plaintiff in Kroger was a citizen of Iowa; the defendant was a citizen of Nebraska, and the claim, for wrongful death of the plaintiff's husband, exceeded $\$ 10,000$, so the case fell within diversity jurisdiction. The defendant impleaded a third-party defendant, against whom plaintiff asserted a claim under Rule 14(a). At the time she asserted the claim, it appeared that she and the third-party defendant were of diverse citizenship; thus there apparently was no supplemental jurisdiction issue. The court and the parties discovered after trial had commenced, however, that the plaintiff and the third-party defendant were in fact cocitzens, meaning, of course, that there was no independent basis of jurisdiction over the claim. See infra note 201.

184. The holding was limited to cases in which the underlying claim invokes diversity jurisdiction. Kroger, 437 U.S. at 377. See C. WRIGHT, supra note $25, \S 76$, at $516-17$. Several courts have subsequently held that supplemental jurisdiction is appropriate over a plaintiff's claim against a nondiverse third-party defendant when the plaintiff's original claim invokes federal question jurisdiction. See, eg., Ortiz v. Umited States, 595 F.2d 65, 73 (1st Cir. 1979); Dick Meyers Towing Serv. v. United States, 577 F.2d 1023, 1025 (5th Cir. 1978), cert. denied, 440 U.S. 908 (1979); Philipson v. Long Island R.R., 90 F.R.D. 644, 645 (E.D.N.Y. 1981); DeMaio v. Consolidated Rail Corp., 489 F. Supp. 315, 316 (S.D.N.Y. 1980).

185. Kroger, 437 U.S. at 377. It is interesting, of course, that the "statutory" factor on which the Court rehed-the requirement of complete diversity-was inserted not by Congress but by the Court's restrictive reading in Strawbridge. See supra text accompanying notes 16-21; see also The Supreme Court, 1977 Term, 92 HARV. L. REV. 57, 248-49 (1978).

186. Kroger, 437 U.S. at 373-76.

187. Id. at 373-77. See generally Chanplin, supra note 99, at 1445 (describing Kroger's discussion of congressional intent as "merely an obfuscating device to mask ad hoc decisionmaking and the lack of any coherent, cohesive or logical policy for determining when to extend jurisdiction to nonfederal claims"). 
Some commentators have suggested other similar factors, arranging them in some "proper" hierarchy to divine congressional intent. 188 Their serious discussion of the Court's multifactored guessing game lends unfortunate credence to an unprincipled approach. Arranging judicially created factors in a judicially perceived hierarchy is not goimg to help determine congressional intent regarding an issue that Congress never addressed. There can be no "congressional intent" in this situation, and the matter ought to be resolved by the presumption in favor of supplemental jurisdiction.

The Court relied principally on two factors in trying to justify its "statutory construction" in Kroger. First, the claim was not "logically dependent" upon resolution of the underlying action. ${ }^{189}$ Second, supplemental jurisdiction was being sought by a plaintiff, not by a defensive party. 190 "True" supplemental jurisdiction claims, then, according to the Court, are logically dependent and are asserted by parties in a defensive posture. This conclusion represents nothing inore than an ephemeral attempt to justify the result of the case.

First, the touchstone of supplemental jurisdiction has always been factual relatedness, not logical dependence.191 The Kroger Court discussed the impleader claim as the archetype for ancillary jurisdiction because of its logical dependence. ${ }^{192}$ Indeed, impleader claims are logically dependent: if the plaintiff loses the underlying action, the impleader claim falls; if the plaintiff wins, the court must address the impleader claim to see whether the loss will be shifted from the defendant to the third-party defendant.

But strict insistence upon logical dependence would significantly narrow supplemental jurisdiction. It would destroy the convenient confluence between the procedural and constitutional tests for joinder and would result in much wasteful collateral hitigation. For example, with regard to counterclaims, Kroger would require the court first to assess the counterclaim's factual relatedness to the underlying action for purposes of classifying it as compulsory or permissive, ${ }^{193}$ then to determine whether the logical dependence test is satisfied so that ancillary jurisdiction may be exercised if necessary.

188. See, e.g., Matasar, supra note 1, at 168-78.

189. Kroger, 437 U.S. at 376.

190. $I d$.

191. See supra text accompanying notes 83-118.

192. Kroger, 437 U.S. at 376.

193. See FED. R. CIV. P. 13(a) (c)mpulsory counterclaim arises from "same transaction or occurrence" as underlying claim); FED. R. CrV. P. 13(b) (permissive counterclaim does not arise from "same transaction or occurrence" as underlying claim). 
Use of the logical dependence standard would also preclude jurisdiction over several familiar claims for which the propriety of ancillary jurisdiction has never been questioned. The Court obviously realized this; after discussing the impleader claim as the archetype, it recognized without criticism the universal acceptance of supplemental jurisdiction over compulsory counterclaims, cross-claims, and claims by and against intervenors of right, ${ }^{194}$ none of which are necessarily logically dependent on the underlying claims. ${ }^{195}$ The Court made no effort to reconcile this recognition with its fetish for logical dependence as to the Rule 14(a) claim before it. 196

Similarly, the fact that the claim in Kroger was not asserted by one in a defensive posture is of little importance. The Court implies that the purpose of supplemental jurisdiction is to promote fairness to the defendant; a defendant precluded from asserting his related claims in the pending litigation would be forced to litigate twice, defending in federal court and pursuing his own claim in state court. The same inconvenience of course can befall the plaintiff too, but this carries less weight with the Court, since the plaimtiff could have packaged the case efficiently by filing in state court in the first place. ${ }^{197}$

This point overlooks the fact that Congress has expressly prescribed a federal forum and the fact that the Federal Rules permit the efficient packaging desired. ${ }^{198}$ Moreover, nothing in the diversity statute or in Strawbridge requires that all assertions by a plaintiff, whenever joined, be supported by an independent basis of jurisdiction. Kroger's implicit assertion to the contrary extends Strawbridge improperly.

c. The unjustified expansion of Strawbridge through mischaracterization of the judicial task. The issue in Kroger was supplemental jurisdiction over a claim joined in accordance with the Federal Rules after the complaint had been filed and after independent action had been taken by another party. The real question before the Court, then, was the scope of

194. Kroger, 437 U.S. at 375 n.18.

195. See 13 C. WRIGHT, A. MILLER \& E. COOPER, supra note $15, \S 3523$, at 102 . The same is true with respect to the flip side of Kroger, that is, with respect to 14(a) claims by the third-party defendant against the plaintiff. Kroger does not affect ancillary jurisdiction over such claims; such jurisdiction is generally allowed. See, eg., Revere Copper \& Brass Inc. v. Aetna Casualty \& Sur. Co., 426 F.2d 709 (5th Cir. 1970).

196. See The Supreme Court, 1977 Term, supra note 185, at 245-46, $252-53$ (criticizing emphasis on logical dependence).

197. See Kroger, 437 U.S. at 376 (efficiency desired by plaintiff available in state court; majority recognizes that its rule produces inefficient results).

198. See Matasar, supra note 1, at 170 ("[T] he Court's presumption against jurisdiction in concurrent jurisdiction cases ignores long expressed congressional desire to preserve a true choice between state and federal courts."). 
the "civil action." Rather than adhere to the broad definitions set out in the Federal Rules and approved in Gibbs, the Court rehed on the narrow interpretations appropriate to the original invocation of federal jurisdiction. Thus, the Court imported the Strawbridge restrictions on the invocation of jurisdiction into the supplemental jurisdiction sphere.

To the extent that Strawbridge is a case of importance to supplemental jurisdiction issues, ${ }^{199}$ it held that a plaintiff carmot join a claim against a nondiverse adverse party as an original matter. ${ }^{200} \mathrm{Mrs}$. Kroger did not do that. Instead, she used an available joinder rule to assert a claim against a third party whom the defendant had impleaded after commencement of the action. 201 Jurisdiction had attached by that point; the civil action was being fleshed out in accordance with the joinder rules and Gibbs.

Strawbridge has never been apphied to preclude supplemental jurisdiction over any claim the plaintiff subsequently asserted against a party over whom jurisdiction was established. ${ }^{202}$ Indeed, after Kroger, a plaintiff remains free to assert several such claims under suppleinental jurisdiction. ${ }^{203}$ Obviously, reading Strawbridge as Kroger apparently did-to apply to every assertion by the plaintiff-is completely inconsistent with the Court's longstanding policy, ${ }^{204}$ restated forcefully in 1967,205 of con-

199. See supra note 157.

200. See Developments in the Law-Multiparty Litigation in the Federal Courts, 71 HARV. L. Rey. 874, 992-95 (1958); Note, Diversity Requirements in Multi-Party Litigation, 58 CoLum. L. REv. 548, 549 (1958); $c f$. Kroger, 437 U.S. at 380 (White, J., dissenting) ("[By requiring complete diversity,] the Court unnecessarily expands the scope of the complete-diversity requirement while substantially limiting the doctrine of ancillary jurisdiction.").

201. Technically, Mrs. Kroger had amended her complaint to include the third-party defendant. But the Court treated the claim against the third-party defendant as though it had been made under Rule 14(a). At first, no one perceived a need for supplemental jurisdiction. Until the third day of trial, everyone apparently assumed that the third-party defendant was a citizen of Nebraska. Thus on the record, the plaintiff's citizenship was diverse from that of the third-party defendant, meaning, of course, that the plaintiff could have pursued a claim directly against that party. The plaintiff did not do so until after impleader by the defendant. Even at that point, there was no jurisdictional problem, since diversity was still presumed to have existed. At trial it was discovered that the thirdparty defendant's principal place of business (which determined its citizenship) was actually in Iowa. The confusion stemmed from the fact that the river that forms the border between the two states had shifted years before, leaving a small "island" of Iowa in Nebraska. In view of this unusual situation, it is ludicrous to suggest that the plaintiff could have been engaging in the kind of gamesmanship the Court found so distasteful. See Krogur, 437 U.S. at 383 \& n.5 (White, J., dissenting); see also Berch, supra note 181 , at $258-59$.

202. See supra note 200.

203. These include claims against intervenors of right and counterclaims against counterclaiming defendants. See FED. R. CIV. P. 24(a)(2); FED. R. Crv. P. 13(a).

204. See Louisville, C. \& C. R.R. v. Letson, 43 U.S. (2 How.) 497, 554-56 (1844) (holding that Strawbridge does not require complete diversity between plaintiff and all shareholders of a defendant corporation).

205. State Farm Fire \& Casualty Co. v. Tashire, 386 U.S. 523, 530-31 (1967). 


\section{struing Strawbridge narrowly.}

The Court erred by treating a joinder issue as a matter of jurisdiction invocation. Its confusion appears to have been caused by its obsessive belief that the plaintiff could have foreseen the joinder of the nondiverse third-party defendant yet opted not to sue it originally, thinking that she would have a later opportunity to assert her claim through Rule 14(a).206 The foreseeability of joinder, however, is absolutely irrelevant to the exercise of supplemental jurisdiction.

d. The irrelevance of foreseeability. The Court rested its holding on its perception of congressional intent, setting forth the irrelevant factors discussed above.207 Its concern with the foreseeability of joinder simply does not reflect congressional intent as to supplemental jurisdiction. Congress has determined that the federal courts' jurisdiction ought to be divested only when a party "has been improperly or collusively made or joined to invoke the jurisdiction of the court."208 Because that statute is not implicated here, it should follow that Congress would not be concerned with the foreseeability of joinder.

Moreover, there is no such preemption of supplemental jurisdiction in other joinder situations where joinder of an absentee is at least as foreseeable. 209 The plaintiff may choose, for example, to sue only one of two potential defendants, "knowing" that self interest will force the nondiverse absentee to intervene ${ }^{210}$ and that intervention of right will carry with it ancillary jurisdiction. ${ }^{211}$ In such a case, the plaintiff is achieving indirectly what he could not achieve directly, yet there is no prohibition of suppleinental jurisdiction; indeed, the Court has noted its general ap-

206. Kroger, 437 U.S. at 374-75.

207. See supra text accompanying notes $189-90$.

208. 28 U.S.C. $\S 1359$ (1982). The majority in Kroger conceded that section 1359 was not satisfied. Kroger, 437 U.S. at 374 n.17.

209. With regard to indispensable parties, however, Rule 19 itself precludes supplemental jurisdiction. FED. R. CIV. P. 19(b). See supra note 90.

210. See Berch, supra note 181, at 258-60; The Supreme Court, 1977 Term, supra note 185, at 245.

211. See, eg., Phelps v. Oaks, 117 U.S. 236 (1886), cited with approval in Kroger, 437 U.S. at 375 n.18. Ironically, Kroger promotes and rewards the very "foreseeing of joinder" it purports to criticize. The wily plaintiff simply unust await the impleader of the third party and the third party's assertion of a Rule 14(a) claim against him. Such claims, probably unaffected by Kroger, carry ancillary jurisdiction. See Finkle v. Gulf \& W. Mfg. Co, 744 F.2d 1015, 1018 (3d Cir. 1984); Revere Copper \& Brass, Inc. v. Aetna Casualty \& Sur. Co., 426 F.2d 709, 711-17 (5th Cir. 1970). Then the plaintiff can assert his claim against the third party as a coinpulsory counterclaim, which must carry supplemental jurisdiction. Some courts addressing the issue after Kroger have reached this conclusion. See, eg., Finkle, 744 F.2d at 1019. This developinent was entirely foreseeable after Kroger. See Case Note, Ancillary and Pendent Party Jurisdiction in the Aftermath of Owen Equipment \& Erection Co. v. Kroger, 28 DRAKE L. REv. 758, 764 n.48 (1979). 
proval of supplemental jurisdiction over claims by intervenors of right. ${ }^{212}$

\section{The 1980's AND BEYOND}

\section{A. The Legacy of Confusion.}

Aldinger and Kroger are unprincipled decisions; they neither espouse nor implicitly adopt a consistent method for approaching supplemental jurisdiction issues. The federal courts had worked out such a system in the century before Aldinger and Kroger, although they failed to indicate expressly the statutory basis for their exercise of jurisdiction. But a plausible statutory basis exists, and is supported both by the traditional canons of statutory construction and by the longstanding congressional acquiescence regarding the judicial definition of the scope of a civil action. 213

Aldinger paid hip service to a presumption consistent with this history and with the principled. approach set forth above. But in applying the presumption, the Court sanctioned unjustified judicial scavenger hunts into legislative history and blurred the independent lines of authority relating, respectively, to invoking original jurisdiction and to packaging a civil action. In Kroger the blurring became blindness to the separateness of the lines, with the Court importing into supplemental jurisdiction doctrine the restrictive rules relating to the invocation of original jurisdiction. The cases direct federal judges to divine a legislative intent that does not exist. Until Congress addresses the point ineaningfully, the quest for legislative imtent is Iudicrous.

The availability of supplemental jurisdiction obviously has an impact on the desirability of invoking federal jurisdiction in the first place.214 Both Aldinger and Kroger foster inefficiency. For example, the practical result in Kroger is that the underlying suit and the defendant's impleader claim against the third-party defendant may be litigated in federal court, while the plaintiff's claim against the same third-party defendant, transactionally related to the other claims, must be pursued in state court. Two lawsuits are required for what is, transactionally defined, one dispute. The plaintiff may avoid this expense and duplication only by abandoning the federal forum and pursuing both claims in state court. ${ }^{215}$

212. Kroger, 437 U.S. at 375 n.18.

213. See supra text accompanying notes $125-43$.

214. See Redish, The Federal Courts, Judicial Restraint, and the Importance of Analyzing Legal Doctrine (Book Review), 85 Colum. L. REv. 1378, 1395-96 (1985) (reviewing R. POSNER, THE FEDERAL COURTS: CRISIS AND REFoRM (1985)) (plaintiff who is unable to achieve packaging in federal court will be tempted to abandon federal forum altogether).

215. Note that this plaintiff has done nothing "wrong," unlike the plaintiff who attempts collusive joinder. See supra note 208 and accompanying text. 
And because the Kroger rule, like that in Aldinger, is a per se prohibition of supplemental jurisdiction, it leaves the trial courts no discretion to exercise jurisdiction. ${ }^{216}$ Thus even in a case where the plaintiff did not actually foresee joinder of the third-party defendant, and in which a trial judge might determine that the interest in packaging outweighed any federalism problem, joinder cannot be effected.

Aldinger and Kroger may be explained as efforts to keep state law claims out of federal court. Aldinger approves of pendent party jurisdiction only where complete joinder cannot be effected in state court. ${ }^{217}$ In all cases in which packaging can be realized in state court-even those involving federal question claims-the plaintiff is offered a strong incentive to go there. Thus the plaintiff who chooses to package his action efficiently by bringing all related claims in one court must eschew the federal forum on the federal question claim.

Kroger is a naked antidiversity case. The deliberate refusal to consider it for what it was-a supplemental jurisdiction case-enabled the Court to expand the application of Strawbridge to order the per se dismissal of clainns satisfying Gibbs. In federal question cases, pendent jurisdiction allows a plaintiff to assert nonfederal claims as an original matter. ${ }^{218}$ In diversity cases, however, a plaintiff now carmot append a subsequent, procedurally proper Rule 14(a) claim against a third-party defendant as to whom the court already has subject matter and personal jurisdiction.

There are policy arguments supporting a harsher treatment of supplemental jurisdiction in the diversity context.219 The Court, however, did not appeal to policy in Aldinger and Kroger. Instead, it based its holdings on congressional intent. Although the issue may be debatable, the Court would be hard put to find meaningful congressional indications that diversity jurisdiction was ineant to be treated as the stepchild of

216. See Berch, supra note 181, at 253 ("[The Court in Owen] creates an enclave of issues which federal courts may be impotent to adjudicate.").

217. See Redish, supra note 214, at 1395 ("[Aldinger] was viewed as a means of reducing federal dockets.").

218. It is fascinating that Gibbs, which upheld pendent jurisdiction where federal question jurisdiction was invoked, suffered all of the defects found important by the Court in Kroger. Specifically, the joined claim was not logically dependent on the federal claim, the plaintiff achieved by indirection what he could not have done directly, and supplemental jurisdiction was asserted over a claim by the plaintiff. The Supreme Court, 1977 Term, supra note 185, at 247-48. Moreover, the plaintiff in Gibbs could have achieved efficient packaging of both of his claims in a single action in state court. Matasar, supra note 1, at 165 \& n.301.

219. These policy arguments have been asserted in the ongoing debate concerning retention of diversity, and need not be repeated in detail here. They include concerns that federal judges cannot render precedential opinions as to matters of state law, that diversity constitutes an unseemly intrusion into matters of state law, and that the federal courts' workload has becoune overwhelming. See supra notes $63-64,76$ and accompanying text. 
federal jurisdiction. 220

Thus this confused brace of cases inay ultimately be seen in interestgroup terms as the imposition of agency costs by an overworked federal bench that is, in some appreciable measure, hostile to diversity jurisdiction. 221 Whether the Cour is ultimately successful in imposing these costs depends on how the lower courts apply the cases and, in turn, on whether the relevant interest group-the organized bar-is so inconvenienced as to seek congressional correction of the precedents.

\section{B. The Wages of Confusion: Ten Years After.}

Because Aldinger and Kroger provided no meaningful guidance on supplemental jurisdiction issues, it is not surprising that the situation in the lower courts is perhaps more chaotic now than it was before those cases were decided. ${ }^{222}$ Altliough some litigants have urged courts to read the cases as an invitation to reassess supplemental jurisdiction in otler contexts, ${ }^{223}$ the cases give no indication of an emerging consensus. ${ }^{224}$

Of course, this is an absurd result. The Court has only spoken twice in a century on the issue of legislative authorization of supplemental jurisdiction. Instead of broad, meaningful pronouncements, the Court has

220. Despite continuing clamor from academics and federal judges for abolition of diversity jurisdiction, see supra note 62 , Congress has done nothing to indicate disfavor with diversity jurisdiction. It has resisted every attempt to abolish it. See supra text accompanying notes 62-71. It has not raised the amount in controversy since 1958; adjusted for inflation, that amount is lower today than it was in 1958. See R. POSNER, supra note 37, at 78-79. It has not expanded the grounds on which a court inay dismiss for inproper joinder. See 28 U.S.C. $\$ 1359$ (1982). It continues to make venue requirements less restrictive in diversity than in general federal question cases. See 28 U.S.C. § 1392 (1982). Congress's reaction to the federal court workload problem has been not to reduce the caseload, but to increase the workforce. See R. PosNer, supra note 37, at 97. This reaction may result in a sense of loss of prestige for those judiges already sitting.

221. See supra note 64 and accompanying text; see also Redish, supra note 214 , at $1397-98$ ("[T]he use of ancillary jurisdiction has been denied plaintiff exclusively in the context of diversity cases, a branch of federal jurisdiction not often favored by federal jurists.").

222. See C. WRIGHT, supra note $25, \S 19$, at 109 (Aldinger has not necessarily had a significant inpact on lower courts); Redish, supra note 214, at 1398 (Aldinger's ambiguities have caused "enormous confusion" in the lower federal courts).

223. See, e.g., Safeco Ins. Co. v. Guyton, 692 F.2d 551, 555-56 (9th Cir. 1982).

224. Regarding confusion in the wake of Aldinger, compare Federal Deposit Ins. Corp. v. Otero, 598 F.2d 627, 630-31 (1st Cir. 1979) (refusing to interpret Aldinger as general bar to exercise of pendent party jurisdiction and emphasizing that Aldinger holding was expressly limited to its facts) with Miletich v. Raley's, 593 F. Supp. 124, 125 (D. Nev. 1984) (refusing to engage in statutory analysis conteinplated by Aldinger where judicial precedent controlling in circuit interprets Article III as prohibiting exercise of pendent party jurisdiction). Regarding confusion in the wake of $K r O$ ger, see supra notes 184,211 . The confusion has not been limited to the federal courts; the unprincipled opinions led to different academic assessinents of their potential impact. Compare Brill, Federal Rule of Civil Procedure 14 and Ancillary Jurisdiction, 59 NEB. L. REV. 631, 640 (1980) (arguing that Kroger "will dominate the area of ancillary jurisdiction for soine time") with Berch, supra note 181, at 260-61 (suggesting that Kroger inight turn out to be of limited importance). 
provided unprincipled, result-oriented cases that have given the lower courts no guidance and have, in retrospect, resolved very little beyond their peculiar facts. The lower courts' reaction clearly bespeaks confusion; it may also indicate a much greater appreciation for packaging than the Supreme Court seems to have.

\section{CONCLUSION}

Only two conclusions can be drawn with any certainty. First, the Supreme Court's dalliance with congressional sanction for supplemental jurisdiction has not provided meaningful guidance. Second, it has not created such a restriction on access to federal court as to pressure Congress to take remedial action. This latter point does not change the fact, however, that the federal courts need a principled, consistent manner in which to approach the statutory authorization of supplemental jurisdiction. I hope that this article has provided one. 